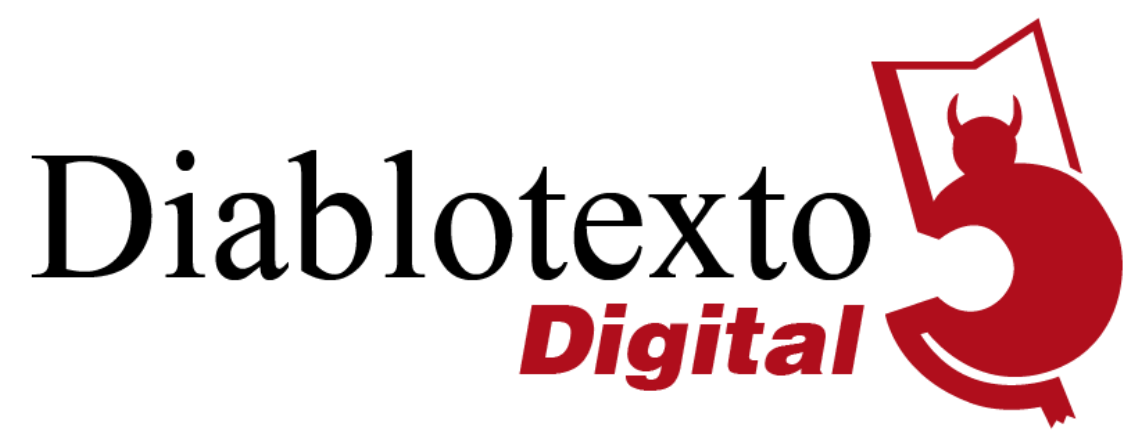

\title{
Hacia un tiempo nuevo: fortunas y adversidades de una Monarquía en transición (1550-1560)
}

Towards a New Era: Fortunes and Adversities of a Monarchy in Transition (1550-1560)

\section{EDUARDO TORRES COROMINAS UNIVERSIDAD DE JAÉN}

Resumen: El artículo ofrece un recorrido por los principales acontecimientos históricos que jalonaron la década de 1550 con el fin de explicar las causas del profundo cambio cultural observado en España a comienzos del reinado de Felipe II. Para ello, se reconstruye la política internacional de Carlos $\mathrm{V}$ (particularmente en el Imperio), se dibuja la evolución de la espiritualidad española desde tiempos del cardenal Cisneros y se analizan las luchas faccionales que dividieron la Corte de los Habsburgo desde comienzos del siglo XVI. Estos tres hilos narrativos confluyen a la postre en el relato pormenorizado de los sucesos acaecidos en el seno de la Monarquía Hispana durante el período de transición entre los reinados del Emperador y el Rey Prudente, que culminarían con el descubrimiento de los focos luteranos de Sevilla y Valladolid y la adopción de una política intransigente y confesional por parte de la Corona.

Palabras clave: Monarquía Hispana, transición, Felipe II, Carlos V, confesionalismo.

Abstract: This article offers a tour along the main historical events that marked the decade of the 1550s to explain the causes of the profound cultural change observed in Spain at the beginning of the reign of Philip II. Too this end, the international policy of Charles V (mainly in the Holy Roman Empire) is reconstructed, the evolution of the Spanish spirituality from the times of Cardinal Cisneros is sketched and the factional strife that divided the Court of the Habsburgs from the beginning of the sixteenth century is analysed. These three narrative threads eventually converge in a detailed account of the events that took place in the Spanish Monarchy during the transition between the reigns of the Holy Roman Emperor and the Prudent King. This culminated in the discovery of the Lutheran foci in Seville and Valladolid and the adoption of an intransigent and confessional policy by the Crown.

Key-words: Spanish Monarchy, transition, Philip II, Charles V, confessionalism. 
La década de 1550 constituye para la historia de España un punto de inflexión de extraordinaria trascendencia, cuyas repercusiones traspasaron con creces los límites del siglo XVI. Se suceden en esos años, en efecto, una serie de acontecimientos decisivos que dieron lugar a un verdadero cambio de época, a la apertura de un tiempo nuevo que coincidió aproximadamente con la abdicación de Carlos V y la subida al trono de Felipe II. Estos hechos, sin embargo, no representaron sino el desenlace, el último episodio de una intrincada trama en la que concurrieron factores políticos, religiosos, sociales y culturales de muy diversa índole. Dar cuenta detallada de todos ellos es tarea que sin duda desborda las posibilidades del presente trabajo. No obstante, trataremos de ofrecer aquí un relato ordenado y sintético de aquellos sucesos destinado a aclarar, primero, la política adoptada por el Imperio Habsburgo a lo largo de aquel decenio -así como los propósitos que la auspiciaban- con el fin de explicar, después, las graves consecuencias que este "cambio de atmósfera" -en palabras de Bataillon- tuvo para el cultivo de las letras y la circulación de las ideas en suelo peninsular. Con ello pretendemos construir un discurso historiográfico preciso y bien trabado que, sin ser exhaustivo, dibuje las líneas maestras de aquel período y sirva como telón de fondo a los diversos estudios que, en el presente volumen, se ocupan de la ficción en prosa trasladada 0 compuesta por entonces en lengua castellana.

Para acometer esta tarea recorreremos a continuación de forma paralela el curso de la política internacional del Emperador -con particular atención al problema del protestantismo en Alemania-, de la espiritualidad española en tiempos de Carlos $V$ y de las facciones surgidas en la Corte de la Monarquía durante aquel reinado, pues todos estos hilos confluyeron de un modo $u$ otro en Ios decisivos acontecimientos vividos en España entre 1550 y 1560, aquellos que alteraron el rumbo de la cultura hispánica tras el regreso a la Península del Rey Prudente y dieron paso a una nueva etapa de nuestra historia moderna marcada por el signo del confesionalismo católico. Se trata, en definitiva, de reunir y evaluar conjuntamente aquellos factores sin los que no es posible reconstruir de manera cabal aquella encrucijada, tras la que se confirmó la fragmentación de la cristiandad entre una Europa católica y otra protestante, 
cesó el clima de tolerancia que había permitido la coexistencia de diversas sensibilidades religiosas y el florecimiento del humanismo en España, y favoreció el progresivo triunfo de los sectores más intransigentes en la Corte de la Monarquía Hispana. De todo ello, en fin, daremos cuenta en las páginas que siguen.

\section{Política internacional de Carlos V: el protestantismo en Alemania}

La abigarrada herencia territorial y la elección de Carlos $\mathrm{V}$ como cabeza del Sacro Imperio Romano-Germánico lo convirtieron en soberano de un inmenso número de reinos y señoríos dispares y dispersos cuyas necesidades y aspiraciones resultaban completamente diferentes. Las dificultades para gobernar este conglomerado político se acrecentaban todavía más por el hecho de que, al margen de pertenecer a un mismo príncipe, aquellas posesiones apenas se hallaban articuladas desde un punto de vista institucional y estaban sometidas a jurisdicciones y fueros muy diversos. Durante cuatro décadas de fatigosa tarea, Carlos V hubo de atender a cada uno de ellos en función de las circunstancias y no siempre llegó a tiempo de acometer los problemas surgidos en los distintos rincones de su Imperio. Sus continuos viajes ilustran elocuentemente las vicisitudes de su reinado, en el que hubo de atender a la presión del Imperio Otomano en el Mediterráneo y el este de Europa; a la constante hostilidad de Francia, que veía amenazada su autonomía ante el creciente poder de los Habsburgo; a las reticencias del Papado, que contemplaba con inquietud la hegemonía española en Italia; y, finalmente, a los príncipes alemanes, que aspiraban a incrementar su independencia con respecto al poder central que representaba el Emperador, y que no dudaron en utilizar el protestantismo para legitimar sus aspiraciones terrenales. En este complejo panorama, la política internacional de Carlos $\mathrm{V}$-más allá de la conservación de sus posesiones patrimoniales- tenía como objetivo tanto la defensa de la cristiandad frente a los infieles como la erradicación de la herejía en el interior de sus fronteras, misiones a las que se sentía llamado -conforme al discurso de los humanistas de su séquito- en virtud de su dignidad imperial. El entramado de intereses puestos en juego, las limitaciones de su hacienda, la 
conveniencia estratégica y la prudencia en el gobierno de sus reinos, sin embargo, provocaron que en numerosas ocasiones la realidad se impusiese a estos altos ideales y marcase la pauta de su política exterior, tal y como aconteció, sin ir más lejos, a la hora de afrontar el problema protestante en Alemania, que desde el surgimiento de Lutero en 1517 no había hecho sino agravarse ${ }^{1}$.

En efecto, tras su condena pública en el edicto de Worms (1521), diversas ciudades y principados apoyaron y protegieron a Lutero, de manera que su disidencia religiosa pronto afectó a la esfera política e interfirió en los vínculos de subordinación trabados entre Carlos $\mathrm{V}$ y sus súbditos alemanes. Tras una década de forzosa contemporización, en la dieta de Spira (1529) todos los asistentes se comprometieron a impedir que la Reforma prosperase en sus territorios. Fue entonces cuando los luteranos, antes que dar un paso atrás, presentaron un escrito de protesta en el que reclamaban mayores libertades para su confesión. Desde entonces, recibirían el nombre de "protestantes". En el otro extremo de la balanza, el Papado, bajo el pontificado de Clemente VII (15231534), se mostraba inflexible ante aquellos herejes, toda vez que su autoridad se hallaba gravemente erosionada por el movimiento de Reforma. En ese sentido, a las discrepancias doctrinales -entre las que destacaba el asunto de la justificación por la fe o la nueva concepción de los sacramentos- los protestantes añadieron la condena moral del estamento clerical, así como la apertura de una vía de relación directa y personal entre los fieles y Dios (sacerdocio universal) que, a través de la lectura directa de las Sagradas Escrituras y del culto en espíritu, no requería ya de la intermediación constante de la Iglesia y sus ministros ${ }^{2}$. Clemente VII, por otra parte, a causa de sus intereses familiares se

\footnotetext{
1 La política internacional de Carlos $\mathrm{V}$ ha sido estudiada, desde diversas perspectivas, por Doussinague (1949: 123-290), Sánchez Montes (1951), Jover (1987 y 2001), Lynch (1993: 8796), Rodríguez Salgado (1996) y Rivero Rodríguez (2001).

2 Las cuestiones dogmáticas y doctrinales que alentaron la teología protestante han quedado resumidas en Martínez Millán (2011: 68-75). En ese sentido, asunto crucial era la cuestión de la salvación (o justificación) del hombre. En la Edad Media, la Iglesia poseía y administraba en exclusiva los sacramentos, entendidos como medio eficiente para la canalización de la gracia divina a través de ritos sagrados oficiados por sus ministros. Sin embargo, los reformadores pretendían convencer a los fieles de que dichos sacramentos no servían para este propósito (representaban solo un gesto conmemorativo), ni las acciones humanas tenían por sí mismas valor suficiente para lograr la reconciliación. Una vez destruido el ciclo penitencial de la teología medieval como consecuencia de un examen minucioso de las Sagradas Escrituras, los
} 
alineó junto a Francisco I en el conflicto que lo enfrentaba al Emperador por el dominio del norte de Italia. Esta manifiesta hostilidad propició el famoso sacco de Roma (1527) y retrasó la convocatoria del concilio general en el que habría de definirse la doctrina oficial de la Iglesia católica. Allí habría de cerrarse también mediante acuerdos el cisma propiciado por el protestantismo alemán, tal y como anhelaba Carlos $\mathrm{V}$, situado en una dificilísima posición intermedia ${ }^{3}$.

A estas alturas, parecía evidente que la paz religiosa resultaba imprescindible para mantener la unión política en el Imperio, pues el luteranismo podía justificar una mayor independencia de los príncipes frente al poder central y reforzar el desarrollo de entidades autónomas donde ellos mismos ejerciesen a un tiempo como autoridad civil y eclesiástica. La obstinación del Papa tampoco facilitó la solución del conflicto, pues bloqueó la celebración de aquel concilio general donde quizás en estos años se hubiese podido alcanzar todavía la concordia. Ante la falta de colaboración por parte del Papado, Carlos V, tras la paz de Cambrai con los franceses (1529), se dispuso a afrontar personalmente el problema religioso en la dieta de Augsburgo (1530), donde las ideas de los reformadores aparecían entreveradas con las quejas y reivindicaciones de la nación alemana. Alí Felipe Melanchthon esgrimió -en el marco de la controversia teológica- la Confessio augustana, que se erigiría en el primer texto confesional protestante ${ }^{4}$. El fuerte arraigo de estas corrientes, unido a la debilidad de su posición, sin embargo, obligaron al Emperador a negociar y a buscar acuerdos en materia religiosa, tal y como pretendían tanto Gattinara como los erasmistas de su séquito. A pesar de sus esfuerzos, los intentos de arbitraje de Carlos $V$ fracasaron, al igual que su oferta de convocatoria de un concilio

reformadores afirmaron que el hombre era un ser esencialmente pecador y que su salvación, por consiguiente, no dependía de sus obras (siempre insuficientes), sino de la infinita misericordia de Dios (esto es, de su voluntad), de los méritos de Jesucristo (redentor de la Humanidad con su pasión y muerte) y de la fe del creyente en su nombre (concebida también como una gracia). Por esta vía, se abrió un nuevo modo de relación entre los fieles y Dios (más íntimo, más vivencial, más directo, sin la necesidad de intermediarios) y se fomentó la lectura de la Biblia (y su libre interpretación) como alimento espiritual del cristiano, mientras que el poder temporal de la Iglesia y su estructura institucional quedaban seriamente dañados.

${ }^{3}$ La política de Carlos $\mathrm{V}$ en el Imperio y la expansión del protestantismo en Alemania pueden conocerse a través de los relatos elaborados por Lutz (1992: 51-100) y Martínez Millán (2000a y 2011: 78-86).

${ }^{4}$ Para un conocimiento más exhaustivo sobre la teología protestante y el pensamiento de Lutero, véanse las obras de García Villoslada (1973), Cargill Thompson (1984), Skinner (1993), Forell (1994), Cameron (2012) y Lazcano (2017). 
general para abordar las cuestiones doctrinales, que sería rechazada por unos y por otros. Es más, como reacción defensiva ante las medidas salidas de Augsburgo, Felipe de Hesse promovió la coalición de los príncipes alemanes en la Liga de Esmalcalda (1531), que contó con el apoyo de Francisco I de Francia, Christian I de Dinamarca y Enrique VIII de Inglaterra, enemigos seculares de Carlos $V$ en la escena europea. Atrapado por las circunstancias y las amenazas exteriores, el Emperador dio muestras de debilidad con su falta de acción ante los príncipes alemanes y los luteranos.

A comienzos de la década de 1540, veinte años después del edicto de Worms, la política de aplazamientos -a la espera de la definitiva convocatoria del concilio- había supuesto en la práctica la tolerancia de las doctrinas reformadas, mientras la posición de los teólogos católicos y protestantes seguía siendo distante. Necesitado del apoyo de los parlamentos alemanes en sus guerras contra Francisco I y Solimán el Magnífico, Carlos V impulsó su propia solución en una nueva dieta, donde fue promulgada la declaración de Ratisbona (1541) por la que se confirmaba la seguridad de los adeptos a la confesión de Augsburgo y se reconocía a los príncipes alemanes el derecho de emprender importantes reformas en los monasterios y otras instituciones religiosas, entre otras concesiones. El papa Paulo III (1534-1549) no aceptó estas medidas que solo sirvieron para confirmar la debilidad del Emperador en aquel avispero centroeuropeo donde se multiplicaban sus enemigos. Animado por su espíritu reformador, el Pontífice impulsó la reunión del concilio general, que finalmente se abrió en Trento (territorio imperial) en diciembre de 1545. Allí debían dirimirse las cuestiones doctrinales sobre las que se fundamentaba la escisión protestante. Dada la compleja situación política, los representantes del Emperador -en ausencia de los teólogos reformados- trataron de impedir una definición dogmática sobre la justificación y los sacramentos, pues eran conscientes de que esto provocaría el inmediato rechazo de los luteranos y confirmaría su negativa a integrarse en la asamblea de la Iglesia universal. Los partidarios de Carlos $\mathrm{V}$ no lo consiguieron y en Trento se apuntalaron las concepciones católicas en aquellas dos cuestiones. Los puentes quedaban de nuevo destruidos y cada vez parecía más evidente que no se retornaría jamás a 
la situación anterior a 1521. El choque (político, militar y cultural) entre ambos bloques sería inevitable, de manera que Carlos $\mathrm{V}$ se vio abocado a tomar las armas en el Imperio contra la Liga de Esmalcalda entrado el año 1546. En este contexto, y gracias a la pericia militar del duque de Alba, Carlos $\mathrm{V}$ obtuvo la célebre victoria de Mühlberg (1547), que después de un cuarto de siglo lo situaba por fin en una posición de fuerza para imponer sus planteamientos políticos y religiosos en Alemania.

El gran triunfo del Emperador, no obstante, dio poco fruto, pues no tardó en generar disensiones dentro del bando católico. Tras la precipitada clausura del concilio de Trento por las diferencias entre los prelados afines a Carlos $V \mathrm{y}$ Paulo III, el Emperador asumió entonces funciones eclesiásticas con independencia del Papado e impuso un nuevo compromiso, el Interim, preparado por sus teólogos en junio de 1548, donde se preservaba la autoridad del Pontífice y la doctrina católica, pero que estaba plagado de concesiones a los luteranos. Como muchos de los textos que lo precedieron, el Interim no fue aceptado ni por los católicos ni por los protestantes, de modo que a la postre no contribuyó a alcanzar la paz religiosa en Alemania. Al mismo tiempo, este incremento de poder trajo consigo el distanciamiento de Carlos $\mathrm{V}$ y su hermano Fernando, archiduque de Austria, toda vez que el Emperador albergaba por aquellos días el sueño de unificar la herencia española, borgoñona y alemana en la persona de su hijo Felipe. Esta opción sucesoria, sin embargo, no resultaba aceptable para los alemanes (católicos y protestantes) que consideraban intolerable la injerencia española en el Imperio. Los Habsburgo de Viena, por su parte, también se posicionaron radicalmente en contra de esta alternativa, pues aspiraban a reunir bajo su cetro un gran imperio centroeuropeo. Con el fin de avanzar en la consecución de este proyecto y de dar a conocer a su hijo en los reinos del norte, Felipe inició en 1548 un viaje por Europa, el felicísimo viaje, mientras María y Maximiliano quedaban como regentes en España. En abril de 1549 se reunió en Bruselas con su padre, donde fue jurado como heredero de los Países Bajos. Acto seguido, pasó a Alemania, momento que aprovecharon las dos ramas de los Habsburgo para celebrar una larga y tensa conferencia familiar en Augsburgo, en el invierno de 1550 a 1551, destinada a sellar el futuro del Imperio. 
La firmeza de Fernando y la manifiesta hostilidad de Maximiliano truncaron allí las pretensiones de Carlos $V$, pues en esta encrucijada se aunaron los intereses del Rey de Romanos -quien ejercía el control sobre Austria, Hungría y Bohemiay los de Alemania, que se negaba a sucumbir bajo el yugo católico y la influencia política y militar de una grandiosa Monarquía Hispánica. De ahí que todos estos factores contribuyesen al reconocimiento de Fernando como sucesor al trono imperial en marzo de 1551, si bien Felipe era situado en la línea sucesoria detrás de su tío y antecediendo al propio Maximiliano. Tras sellarse aquel compromiso entre los Habsburgo y dado por concluido el felicísimo viaje, el príncipe heredero -junto con sus más leales servidores- no tardaría en regresar a España para ponerse al frente de la regencia. Desde allí habría de contribuir a la política del Imperio mediante la obtención de recursos excepcionales y un diligente manejo del gobierno donde pronto manifestaría su creciente madurez e independencia, situado ya en los umbrales del poder.

\section{La espiritualidad en la España de Carlos V}

En paralelo a los sucesos acaecidos en Alemania en torno al movimiento protestante, en el interior de la Península la primera mitad del siglo XVI constituyó un período de particular efervescencia espiritual, donde reformadores, humanistas, teólogos y fervorosos fieles dieron aliento a numerosas formas de devoción que coexistieron (o se enfrentaron) en un contexto cada vez más convulso debido a las noticias procedentes del exterior. Muchas de estas corrientes, en rigor, representaban un impulso de reforma dentro del catolicismo que se anticipó en varias décadas al luteranismo y que vino acompañado de un renacer cultural e intelectual cuyo fruto sobrepasó con creces los límites de una mera enmienda o corrección de las desviaciones más evidentes. De hecho, algunos de los vectores más fecundos de esta reforma católica resultarían cruciales para la obra de Trento, donde servirían para la configuración dogmática e institucional de la nueva Iglesia.

Si hemos de buscar un punto de partida para nuestro relato, habremos de retroceder a la centuria anterior, cuando los rescoldos del cisma de Occidente, el progreso del poder monárquico, la degeneración moral del clero, el 
agotamiento de la escolástica y el ritualismo predominante en la práctica religiosa -culto a los santos, reliquias, bulas, indulgencias, ayunos, limosnas, peregrinaciones, etc.- invitaban a una profunda reforma de la Iglesia, tal y como reclamaban los espíritus más exigentes ${ }^{5}$. A pesar de las medidas aprobadas con esta vocación en los Concilios ecuménicos de Constanza (1414-1418) y BasileaFerrara-Florencia-Roma (1431-1445) -destinados a enderezar la nave de san Pedro-, muchas de aquellas nunca se ejecutaron y quedaron pendientes, mientras la disputa entre papistas y conciliaristas bloqueó en las décadas siguientes un decidido avance en esta línea. Dadas las circunstancias -y ante la imposibilidad de impulsar un cambio general desde la cabeza- se emprendieron reformas parciales, in membris, encaminadas a renovar por partes (y desde la base) diversos sectores de la institución eclesial. En España, quien inició esta labor de un modo más enérgico fue Isabel la Católica, en cuyo círculo cortesano florecía una intensa espiritualidad que desde la cúspide de la Monarquía dio aliento a numerosas iniciativas reformadoras. Para su ejecución, se sirvió de hombres de su máxima confianza, como fray Hernando de Talavera o el cardenal Cisneros, quienes emprenderían a lo largo de aquel reinado una intensa labor política y cultural de honda repercusión para la historia de España. La figura clave de aquel movimiento fue Francisco Jiménez de Cisneros, quien, tras salir de la vida retirada y ser situado por voluntad de Isabel en la primera línea política, acumuló un extraordinario poder que empleó con decisión en la consecución de sus objetivos. Su programa de reforma religiosa e intelectual se fundamentó en tres líneas de actuación: renovación administrativa e institucional de conventos, monasterios y episcopados; reavivamiento de la piedad popular por medio de traducciones al romance de obras pías; y la fundación de la Universidad de Alcalá de Henares (1508), consagrada a los estudios teológicos. Este programa, como se observa, se proyectaba sobre la sociedad en tres niveles: eclesial, pastoral y académico, con estrechas conexiones entre ellos ${ }^{6}$.

\footnotetext{
${ }^{5}$ Las formas de devoción predominantes en el otoño de la Edad Media han quedado descritas en Huizinga (1978: 213-285).

${ }^{6}$ La vida y las grandes empresas del cardenal Cisneros han sido estudiadas exhaustivamente por García Oro (1992 y 2002) y Pérez (2014). Resultan de gran utilidad las síntesis sobre la reforma católica en España que ofrecen Lynch (1992: 77-86), Andrés Martín (2000) y Martínez Millán (2001 y 2011: 110-128), a quienes seguimos en sus líneas maestras.
} 
En el ámbito eclesiástico, las reformas de Cisneros tuvieron buena acogida entre las órdenes religiosas, en particular, las mendicantes, donde el espíritu de austeridad que encarnaba el arzobispo de Toledo caló con hondura gracias al movimiento de la observancia, amparado por la Corona y sancionado por Roma. Para su ejecución, se enviaron visitadores, se nombraron nuevos abades y priores y se reformularon las reglas monásticas. La observancia, sin embargo, no fue igual entre los dominicos y los franciscanos. Mientras la Orden de Santo Domingo, bajo la dirección de fray Diego de Deza, siguió una vía más intelectual (acorde a su tradición tomista), donde la vida de oración, la consagración al estudio, la observancia regular y el compromiso con el apostolado se erigieron en pilares de su forma de vida consagrada; los frailes menores se inclinaron hacia unas formas de devoción más afectivas e intimistas, donde se fomentaba el culto en espíritu, la literatura devota en lengua romance, la recepción frecuente de los sacramentos -en particular, la eucaristía- o la práctica de la oración mental. Unos y otros, intelectualistas y místicos, en suma, representaban a grandes rasgos las dos principales familias de la espiritualidad española en la primera modernidad, cuyas posturas entrarían en conflicto al radicalizarse el problema confesional en el tablero europeo. A modo de síntesis, podemos afirmar que entre los primeros predominaba una mentalidad racionalista y conservadora, fiel a la ortodoxia, a los dictados de la tradición canónica y al método escolástico, que pretendía acceder a la divinidad a través del intelecto, la liturgia y las ceremonias, pero que muchas veces derivaba en una grave sequedad espiritual y un acusado formalismo en el cual, no obstante, las autoridades civiles y religiosas encontraban un medio eficiente para el control social. Entre los segundos, por el contrario, abundaba la práctica de una religión inspirada y afectiva -de vocación renovadora- que los animaba a buscar a Dios en el corazón mediante la voluntad, la oración mental y la comunión en el espíritu, dando lugar a una fe vivencial e intimista que, sin embargo, podía desviarse fácilmente hacia la heterodoxia o la herejía a causa del fervor exaltado y del iluminismo, como sucedió con los alumbrados en Castilla ${ }^{7}$.

\footnotetext{
${ }^{7}$ Acerca de la reforma cisneriana en el clero secular y las órdenes monásticas, son de obligada lectura las reflexiones de Bataillon (1966: 1-10).
} 
Para comprender en profundidad el asunto, es necesario esbozar al menos la cuestión de esta secta iluminista de origen exclusivamente español cuyo surgimiento precedió en varios años al luteranismo en Alemania. Aunque no pueden precisarse con claridad los orígenes del movimiento, parece que el primer foco alumbrado debe situarse en el antiguo reino de Toledo, en el palacio ducal de Guadalajara y al amparo de los Mendoza, más adelante duques del Infantado. En aquel entorno confluyeron Isabel de la Cruz, Pedro Ruiz de Alcaraz y María Cazalla. La primera, precisamente, fue quien introdujo cierta sistematicidad al movimiento, pues ya en 1512 predicaba la sumisión de la voluntad humana a Dios. Su discípulo Pedro Ruiz de Alcaraz, buen conocedor de las Sagradas Escrituras y de la literatura mística, entró después, en 1523, al servicio del viejo marqués de Villena, Diego López Pacheco, entusiasta seguidor de los franciscanos y dedicatario del Tercer abecedario espiritual de Francisco de Osuna. Fue en su palacio de Escalona donde Alcaraz reunió un primer grupo de seguidores a los que transmitió los principios pasivos del dejamiento 0 sometimiento absoluto a la voluntad de Dios, que implicaba orillar en las prácticas devotas todo ritualismo externo ajeno a la meditación, esto es, el ayuno, la oración vocal, la confesión... A su predicación acudía buena parte de la servidumbre del marqués, entre los que se contaba el joven paje Juan de Valdés. A partir de ese foco, pronto surgieron otros en el entorno de Guadalajara, como los de Cifuentes y Pastrana, del que formaba parte María Cazalla. Paralelamente surgió un segundo foco alumbrado en el eje conformado por Salamanca, Valladolid y Logroño, por el que transitaron importantes figuras del iluminismo castellano como Francisca Hernández, el bachiller Medrano (cura de Navarrete ligado a la familia del duque de Nájera) y Bernardino Tovar, hermano del célebre humanista Juan de Vergara. Muchos de ellos eran conversos que anhelaban una fe vivencial que superase la sequedad del formalismo religioso. Aunque no poseían una sólida preparación académica, estos espíritus inconformistas se sirvieron a discreción de la literatura mística que, gracias a la labor cultural promovida por Cisneros, circulaba desde hacía años en lengua vernácula a través de ediciones impresas. Estos alumbrados se reunían en 
conventículos donde se comentaba la Biblia y se daba rienda suelta a un fervor religioso que recibía su inspiración directamente de Dios, al margen de la autoridad de la Iglesia. Sumidos en un extático abandono, consideraban que se hallaban en tal estado de pureza que no podían pecar, lo cual incluso los indujo a pensar en la inutilidad de las obras para el camino de salvación del hombre. Amparados en esta creencia, algunos emplearon este pretexto para dar rienda suelta a sus pasiones carnales, tal y como quedó recogido en los procesos inquisitoriales seguidos contra los miembros de la secta. Fue precisamente la Inquisición de Toledo la que en 1525 promulgó un edicto especial contra los alumbrados donde se condenaban por heréticos cuarenta y ocho de sus postulados. Todo el movimiento quedó entonces condenado y se cercenó con ello la posibilidad de una reforma religiosa a nivel popular, independiente del misticismo, del erasmismo y del luteranismo. A partir de entonces, el Santo Oficio mantendría siempre una estrecha vigilancia sobre quienes, dominados por el entusiasmo religioso, resultasen sospechosos de iluminismo ${ }^{8}$.

Por este camino es posible enlazar con la segunda línea de actuación emprendida por Cisneros, de marcado acento cultural, consistente en la promoción de la literatura devota en lengua vulgar con intención de favorecer la espiritualidad del pueblo llano. Así, de acuerdo con la reina Isabel, impulsó la traducción y publicación de obras espirituales como las de san Bernardo, santa Ángela de Foligno, santa Catalina, san Juan Clímaco o Hugo de Balma, todas de inclinación ascética y mística, que eran lectura frecuente en otras regiones de Europa. De hecho, como consecuencia de esa sensibilidad compartida, se publicaron en la Península textos de procedencia nórdica, como la Imitación de Cristo del agustino Tomás de Kempis, De Quatuor Hominis Novissimis de Dionisio Cartujano y el Tractatus de spiritualibus ascentionibus de Gerardo Zutphen; y se popularizaron las obras místicas de Jan van Ruysbroek, Johannes Tauler y Heinrich Seuse, a quienes precedió Enrique de Herp con su Espejo de

\footnotetext{
${ }^{8}$ Sobre los alumbrados son esenciales los trabajos clásicos de Márquez (1972) y Andrés Martín (1973). Véanse también las páginas dedicadas al iluminismo castellano y su relación con el erasmismo por Bataillon (1966: 166-225) y Huerga (1986).
} 
perfección ${ }^{9}$. Todos ellos constituyeron sabroso alimento espiritual para los españoles y acompañaron los albores del recogimiento, precedente directo de la mística en tiempos de Carlos V. Sin traspasar los límites de la ortodoxia, esta tendencia, surgida en el entorno de la observancia franciscana a finales del siglo $\mathrm{XV}$, se caracterizó por el rechazo de la teología especulativa, por un marcado antiintelectualismo, por la asunción de una vida virtuosa despojada de los vicios mundanos, por la práctica sistemática de la oración mental y por una ascesis exigente de mortificaciones. Con todo, puede afirmarse que el período fundacional, en el que se compusieron sus textos esenciales, aquellos que servirían como punto de partida a la mística de nuestro Siglo de Oro, se escribieron durante el reinado del Emperador, momento en que aparecieron obras como el Tercer abecedario espiritual (1527) de Francisco de Osuna, Vía spiritus (1531) de Bernabé de Palma y la Subida al Monte Sion (1535) de Bernardino de Laredo. Esta fue la época dorada del recogimiento, cuando los franciscanos abrieron numerosas casas de oración autorizadas por Francisco de Quiñones. Unos años más tarde, el influjo de esta espiritualidad recogida traspasaría los muros de palacio y calaría profundamente en algunos miembros de la familia real, como doña Juana de Austria, así como en buena parte de sus servidores, que la practicaron fervientemente ${ }^{10}$.

Como colofón a toda su labor, la fundación de la Universidad de Alcalá de Henares (1508) representó la gran apuesta cultural del cardenal Cisneros para reformar la Iglesia, pues su objetivo fundamental era crear una institución académica destinada a elevar el nivel de preparación del clero y a formar a las nuevas elites eclesiásticas españolas. Inspirada en el espíritu franciscano y evangélico de su promotor, Alcalá destacó por sus estudios de teología, que primaron siempre sobre los jurídicos. Como prueba de esta inclinación, frente al tomismo predominante en Salamanca, en la Universidad Complutense se conformaron nuevas cátedras dedicadas a Escoto y a los nominalistas, dos ramas alternativas de la escolástica que rivalizaban con la herencia racionalista

\footnotetext{
${ }^{9}$ El listado de obras que Cisneros mandó traducir del latín para favorecer la devoción popular se recoge en Nieto (1979: 96-97). En esa línea, son interesantes las reflexiones de Bataillon (1966: 44-51) sobre la vulgarización de la Escritura, los padres y los místicos.

${ }^{10}$ Los principales autores y obras del recogimiento español han recibido adecuado tratamiento en Andrés Martín (1975).
} 
del dominico. Como consecuencia de este impulso intelectual, que pronto la convirtió en un centro de primer orden gracias a la promoción de las humanidades, las lenguas y la medicina, cobró forma el proyecto de la Biblia Políglota. La obra constituyó la máxima expresión del humanismo cristiano en España y puso de manifiesto el interés por los estudios bíblicos en la Península antes de la emergencia de Lutero. En ambos casos, no obstante, la motivación que animaba la tarea crítica era semejante: la depuración textual de las Sagradas Escrituras, que habrían de erigirse en piedra angular de una renovación espiritual de corte evangélico. De hecho, la maduración del biblismo en el ámbito hispánico coincidió en el tiempo con otras iniciativas análogas que por entonces florecían en el norte de Europa, donde Erasmo de Rotterdam, sin ir más lejos, trabajaba por aquellos días en su traducción del Nuevo Testamento (1516) a partir de testimonios en griego ${ }^{11}$. Conforme avanzó la centuria y se agravó la escisión protestante en Alemania, sin embargo, estas prácticas filológicas fueron miradas con creciente recelo, pues la enmienda, traducción y difusión de las Sagradas Escrituras pasaron a ocupar un lugar central en la controversia religiosa una vez que la imprenta y el empleo de las lenguas vernáculas multiplicaron el impacto social de las nuevas corrientes espirituales. Como telón de fondo, se hallaban en juego la autoridad de la Vulgata, el prestigio de la tradición de la Iglesia, la obediencia a Roma, los riesgos de la libre interpretación de la Escritura y la amenaza de una espiritualidad popular difícil de controlar y susceptible de degenerar en herejía ${ }^{12}$.

Las corrientes surgidas al calor del franciscanismo y los estudios bíblicos de Alcalá constituyeron el mejor caldo de cultivo para la recepción del erasmismo en España ${ }^{13}$. En ese sentido, hemos de considerar el rechazo al formalismo religioso y al método escolástico, así como el regreso a los textos fundamentales del cristianismo, como sustrato común que favoreció el rápido acomodo de

\footnotetext{
${ }^{11}$ Las relaciones entre el biblismo y el erasmismo en la España del siglo XVI han sido estudiadas por Fernández Tejero y Fernández Marcos (1986).

${ }^{12}$ La fundación de la Universidad de Alcalá de Henares y la empresa de la Biblia Políglota han recibido tratamiento particular en Bataillon (1966: 10-44).

${ }^{13}$ Sobre la primera recepción de Erasmo en España, véase el trabajo de Andrés Martín (1986).
} 
aquellas ideas en nuestra tradición ${ }^{14}$. Con su recepción y arraigo se inicia, en rigor, una nueva fase en el Renacimiento español, donde reformismo evangélico y legado clásico se dieron la mano -baste citar los Coloquios o los Adagios de Erasmo- en una veta de extraordinaria fecundidad para las letras hispánicas. En líneas generales, su discurso alternaba un encendido evangelismo que abogaba por el regreso a la sencillez de los tiempos apostólicos, con el manejo de una afilada pluma que, preñada de elocuencia, no dudaba en emplear para zaherir a los corruptos en pro de la reforma de la Iglesia ${ }^{15}$. Su incuestionable talento le permitió contar con el apoyo de influyentes servidores de Carlos V, como Alfonso de Valdés, y conquistar la voluntad de las dos dignidades eclesiásticas más importantes de España: Alonso de Fonseca, arzobispo de Toledo; y Alonso Manrique, arzobispo de Sevilla e inquisidor general.

A pesar de confirmar su distanciamiento de las posiciones cismáticas de Lutero, las voces discrepantes contra Erasmo propiciaron la convocatoria en 1527 de la conferencia de Valladolid con el fin de evaluar su ortodoxia ${ }^{16}$. En aquella ocasión, los textos erasmianos salieron indemnes del escrutinio, pero la Inquisición no tardaría en derribar las barreras defensivas de los humanistas tanto en la Corte como en las universidades. En efecto, cuando Carlos $\mathrm{V}$ regresó a España en 1533 la Inquisición había logrado asociar, a ojos de la opinión pública, el pensamiento de Erasmo con las doctrinas de Lutero, lo que obligó a muchos erasmistas a huir del país o a atemperar sus planteamientos. Otros, para su desgracia, caerían en manos de la Inquisición y serían procesados en un clima de creciente intransigencia. Esto sucedió con el humanista Juan de Vergara, secretario en Toledo del arzobispo Fonseca, detenido en 1533, o con Pedro de Lerma, primer rector de la Universidad de Alcalá, procesado en 1537. Ambos serían obligados a retractarse públicamente allí donde habían predicado. Otros encausados por su filiación erasmista fueron el editor Miguel de Eguía,

\footnotetext{
${ }^{14}$ El entorno académico alcalaíno en que se recibió la obra de Erasmo ha quedado descrito en Bataillon (1966: 154-165).

${ }^{15}$ Las novedades que trajo consigo el humanismo con respecto al pensamiento medieval y al método escolástico han sido expuestas de manera sintética por Pérez (1978) y Cilveti (1986). En ese contexto, Asensio (1952) reflexiona sobre las diversas vetas de la escritura erasmiana, mientras que Morón (1986) estudia las fuentes y la originalidad de su sistema.

${ }^{16}$ Un examen pormenorizado de la conferencia de Valladolid se halla en Bataillon (1966: 226278).
} 
Mateo Pascual, Miguel de Mezquita y Juan del Castillo. En 1536 moría Erasmo y ese mismo año eran prohibidos sus Coloquios en romance. Al siguiente, la Universidad de París los condenaba por completo ${ }^{17}$. En 1538 Alonso Manrique seguía los pasos del maestro. Con él desaparecía el último protector del erasmismo que todavía conservaba un puesto de relevancia en la política española. Como escribía Juan Luis Vives en una conocida carta dirigida al propio Erasmo: "estamos pasando por tiempos difíciles en que no se puede hablar ni callar sin peligro [...] Ruego al cielo que te dé una vejez tranquila" ${ }^{18}$. En 1538, a consecuencia de estos sucesos, la expresión abierta del erasmismo en España tocaba a su fin a pesar de su ortodoxia y de que no se percibiese en la Península la amenaza real del luteranismo, tal era la penetrancia de la reforma católica iniciada a finales del XV y el rechazo generalizado que despertaba el monje de Wittemberg al sur de los Pirineos ${ }^{19}$.

A lo largo de este período, la Inquisición tuvo dificultades para reconocer con claridad las características propias y distintivas de las diversas corrientes heterodoxas que proliferaron como consecuencia de aquella efervescencia espiritual desatada por la observancia, el recogimiento, el evangelismo y el humanismo cristiano, mezclados tantas veces en la experiencia personal de los fieles ${ }^{20}$. Así, alumbrados, erasmistas y luteranos fueron en numerosas ocasiones identificados y confundidos por el Santo Oficio que, sin entrar en muchas disquisiciones, los consideraba partícipes de una misma herejía que debía ser combatida y extirpada para la defensa del catolicismo ${ }^{21}$. Sea como fuere, el propósito de reforma, el humanismo cristiano, la vocación evangélica y las corrientes místicas no desaparecieron a partir de 1530 a pesar de la presión

\footnotetext{
${ }^{17}$ Los tiempos, modos y lugares en los que fue censurada la obra de Erasmo han sido estudiados de manera particular por Torres García (2017).

${ }^{18}$ Carta enviada por Juan Luis Vives a Erasmo de Rotterdam el 10 de mayo de 1534, recogida fragmentariamente en Bataillon (1966: 490).

19 La persecución de los erasmistas españoles durante la década de 1530 ha sido narrada elocuentemente por Bataillon (1966: 432-493).

${ }^{20}$ Sobre la relación entre el erasmismo y las corrientes espirituales afines (el biblismo y la tradición hebraica, el iluminismo castellano y la literatura espiritual italiana) reflexionó, volviendo sobre autores y obras, Asensio (1952) en su trabajo clásico, donde se dibuja un panorama cultural extraordinariamente complejo dominado por la diversidad de experiencias particulares.

${ }^{21}$ En esa confusión de corrientes heterodoxas constituyó un hito el proceso inquisitorial contra Juan de Vergara, acusado de alumbrado, erasmista y luterano. Al respecto, véanse los trabajos de Selke (1952) y Longhurst (1956-1963).
} 
inquisitorial. Así lo acreditan el crecimiento de la Compañía de Jesús -cuyo carisma en sus primeros tiempos estuvo muy ligado al recogimiento- con insignes figuras como Ignacio de Loyola o Francisco de Borja; la actividad intelectual y apostólica de destacados dominicos como Bartolomé Carranza o fray Luis de Granada; o del grupo de teólogos vinculado a la catedral de Sevilla -Juan Gil (el doctor Egidio), Francisco de Vargas o Constantino Ponce de la Fuente (el doctor Constantino), todos ellos procedentes de Alcalá-, que desde los márgenes de la heterodoxia -defendieron proposiciones muy cercanas a la justificación por la fe- desarrollaron una fecunda labor como predicadores y autores devotos. Unos y otros, en mayor o menor medida, tuvieron problemas con la Inquisición y, llegada la década de 1550, hubieron de padecer los rigores de un tiempo nuevo donde no se hicieron concesiones a la heterodoxia ni hubo espacio ya para una vía media entre las distintas confesiones en litigio ${ }^{22}$.

\section{La lucha faccional en la Corte de Carlos V}

Para comprender muchas de las decisiones adoptadas por la Monarquía en la escena internacional y en el ámbito de la espiritualidad, no obstante, resulta imprescindible conocer la historia de la Corte, pues la consolidación del poder central durante el reinado de los Reyes Católicos propició que en este ámbito se dirimieran los principales asuntos concernientes al gobierno de la Monarquía. Así, con el predominio de la Corona sobre la aristocracia, el clero y las oligarquías urbanas, la Corte se convirtió en el espacio de confluencia donde se articulaban las relaciones entre los monarcas y los distintos estamentos. Gracias a estos vínculos no institucionales, aquellos cortesanos obtenían cuantiosos oficios y prebendas a cambio de su fidelidad personal (y la de aquellos señoríos y ciudades donde ejercían su dominio), que por esta vía fueron cayendo paulatinamente bajo la órbita de influencia de la Monarquía. La lógica del servicio-merced, por consiguiente, presidía todo el sistema, para el que resultaba clave la administración prudente de la gracia real, a través de la cual se redistribuía el inmenso poder acumulado en manos de la Corona. Aquel

\footnotetext{
22 Una visión panorámica sobre la actuación de la Inquisición española en tiempos de Carlos $\mathrm{V}$ se halla en Kamen (1999: 85-103) y Martínez Millán (2007: 90-96).
} 
engranaje, en todo caso, funcionaba de manera efectiva por medio de grupos de poder o facciones cortesanas que canalizaban la gracia, de arriba abajo, a través de tupidas redes clientelares dominadas por quienes, erigidos en grandes patronos, podían influir en la voluntad del príncipe gracias a su prestigio, su autoridad, su cercanía o su carisma personal. En torno a ellas se reunieron y organizaron, por tanto, aquellos individuos que, en el universo áulico, compartían unos mismos intereses, un mismo origen, una misma concepción política o una determinada sensibilidad religiosa. En consecuencia, solo mediante el conocimiento empírico de aquellas facciones cortesanas (de sus principales miembros, de su evolución interna y de su capacidad de influencia), así como de la ideología y espiritualidad predominantes en su seno (aquellas que conformaban su identidad y orientaban la actuación política de sus integrantes) estaremos en disposición de interpretar cabalmente los acontecimientos históricos y la deriva tomada por la Monarquía Hispana en la década de 1550. Los hechos acaecidos entonces constituyeron el desenlace de una cruenta lucha faccional librada en las más altas esferas de la Corte bajo la que subyacía, sin embargo, más allá de los intereses particulares que allí concurrieron, el enfrentamiento entre dos maneras opuestas de entender la política y la religión cuyo origen se hallaba, una vez más, en el reinado de los Reyes Católicos.

En efecto, hasta finales de la década de 1490, en la Corte castellana un influyente grupo de servidores, entre los que se contaban Hernando de Zafra, fray Hernando de Talavera o el mismo Francisco Jiménez de Cisneros, pusieron en ejecución una vigorosa política inspirada en la iniciativa y carisma personal de Isabel la Católica. Esta línea de actuación se fundamentaba no solo en un fuerte regalismo, sino también en un celo religioso que propició el comienzo de la reforma católica en España a través de movimientos como la observancia. Este rigor, sin embargo, no era incompatible con un espíritu de tolerancia que defendió siempre la igualdad entre judeoconversos y cristianos viejos, promovió los métodos de conversión pacífica de las minorías hebrea y musulmana -a través del ejemplo y la predicación- y rechazó, por lo general, los métodos expeditivos de la Inquisición, tantas veces empleados de manera arbitraria para resolver cuestiones personales. Desde este sector de la Corte se protegió 
también el humanismo y la literatura devota con el fin de incentivar la piedad de los súbditos a través de la nueva cultura impresa.

Frente al partido isabelino o castellano se conformó en torno al Rey Católico el llamado partido fernandino o aragonés, constituido en un principio por servidores que pasaron desde Aragón a Castilla tras la unión de reinos, al que pronto se sumaron nuevos efectivos propiamente castellanos. Entre estos se hallaban Tomás de Torquemada, Juan Rodríguez de Fonseca, Diego de Deza, Francisco García de Loaysa o el duque de Alba, así como Francisco de los Cobos y Juan Pardo de Tavera, todavía muy jóvenes en esta época. Por lo general, poseían una visión más pragmática y descarnada de la política hispana y no dudaban en emplear métodos violentos para la imposición de sus postulados. En lo que respecta a la espiritualidad, se identificaban con la tradición escolástica, el intelectualismo tomista y el formalismo religioso, que esgrimían como celosos defensores de la ortodoxia frente a otras formas de devoción más exaltadas y potencialmente peligrosas, como aquellas que derivaban de la renovación franciscana. Asimismo, se mostraron implacables contra los falsos conversos y permanecieron siempre vigilantes ante aquellos otros que, aunque sinceramente convertidos, rechazaban el ritualismo vacuo y el espíritu de cruzada (erigidos en seña de identidad de la comunidad cristianovieja) y exploraban otras vías de espiritualidad menos seguras. Por ello, no es de extrañar que desde las filas del partido fernandino se impulsase la implantación de la Inquisición española (1478), que muy pronto demostró su eficacia como instrumento de control social al servicio de la Corona.

Este bipartidismo todavía dividía la Corte española a comienzos del reinado de Carlos V, si bien el grupo conformado por Cobos y Tavera, heredero del partido aragonés, fue ganando paulatinamente posiciones al colocar a muchos de sus miembros en puestos clave de la administración, comenzando por la Cámara Real, a través de la que se canalizaba la gracia, y el Consejo de Estado, donde se decidía la política internacional de la Monarquía. Desde allí prosiguieron su expansión por medio de la recomendación y el patrocinio, que les permitió introducir progresivamente a sus partidarios en los Consejos de Castilla (presidido por Tavera entre 1524 y 1539), de Indias, de Cruzada y de 
Inquisición ${ }^{23}$. El predominio de estos hombres pronto repercutió en la política española y se sintió en asuntos como la junta sobre los alumbrados, donde se percibió ya el avance de la intransigencia. La expulsión de la Corte de Alonso Manrique en diciembre de 1529 puso el Santo Oficio en manos del Consejo de Inquisición, que se vio facultado para iniciar una política más férrea de vigilancia y represión de las corrientes heterodoxas ${ }^{24}$.

Pocos años antes, en 1526, la llegada de Isabel de Avís a Castilla para desposarse con Carlos V había introducido algunas novedades en la Corte española cuya repercusión a largo plazo sería extraordinaria. En efecto, su Casa había quedado organizada a la manera portuguesa y muchos de sus miembros eran de ascendencia lusitana. Isabel era nieta de los Reyes Católicos y había recibido por vía materna una estricta educación religiosa cuyas raíces se hallaban en el riguroso espíritu de la observancia. Esta espiritualidad era compartida mayoritariamente por su servidumbre portuguesa, que, andados los años, incidiría decisivamente sobre la educación del príncipe Felipe y llegaría a cuajar en un grupo de oposición a la facción dominante. Así las cosas, en el contexto cortesano antes descrito, resulta lógico que los partidarios de Alonso Manrique se agrupasen a lo largo de la década de 1530 en torno a las figuras de la Emperatriz y del príncipe Felipe, con el fin de influir en su formación y hacer triunfar su ideario tras la sucesión al trono.

Todos estos movimientos, en todo caso, no pasaron desapercibidos para la facción de Cobos y Tavera, quienes trataron de apartar a los servidores de la Casa de la Emperatriz del entorno del Príncipe para combatir esta amenaza. De ahí que se promoviese la creación de una Casa propia para el heredero, que se organizó al modo castellano. A pesar de todo, esta facción no controló los nombramientos de la mayoría de los oficiales y servidores, comenzando por el del nuevo ayo, don Juan de Zúñiga, hermano del conde de Miranda, mayordomo

\footnotetext{
${ }^{23}$ La evolución interna de la Corte española durante la minoría del príncipe Felipe, período de hegemonía de Cobos y Tavera, puede conocerse a través de Martínez Millán y De Carlos (1998: 31-34). Acerca de la organización y composición de los Consejos, véase De Carlos (2000) y sobre el Consejo de Inquisición, Martínez Millán (1988). Una exhaustiva biografía del secretario Francisco de los Cobos fue ofrecida por Keniston (1980), donde se reconstruye muy por extenso su trayectoria cortesana y su red clientelar.

${ }^{24}$ Las transformaciones operadas en el Santo Oficio durante la primera etapa del reinado de Carlos V pueden conocerse por medio de Avilés (1984).
} 
mayor de la Emperatriz, a quien debió el oficio. Así pues, desde 1535 Zúñiga favoreció la incorporación a la Casa del Príncipe de nuevos servidores como, por ejemplo, Ruy Gómez de Silva, quien ingresó entonces como trinchante tras haber ejercido desde 1526 como menino en la Casa de la Emperatriz ${ }^{25}$. En aquel entorno crecía el heredero, cuya formación se conformaba con el modelo educativo establecido por prominentes humanistas como Bernabé de Busto o Lucio Marineo Sículo, quienes dedicaron por estos años importantes obras pedagógicas al joven Felipe ${ }^{26}$. En torno a las Casas de la Emperatriz y del Príncipe, en consecuencia, se configuró en la década de 1530 un nuevo grupo de cortesanos cuya relación de nombres tenía sabor de alternancia ${ }^{27}$.

La muerte de la emperatriz Isabel en 1539 y la inminente partida de Carlos $\checkmark$ hacia el Imperio provocaron importantes cambios en la vida del príncipe Felipe, quien aprendió entonces sus primeras nociones de política. En 1543, finalmente, partió el Emperador hacia Alemania, mientras su hijo, todavía adolescente, permanecía en la Península al frente de la regencia. Dada su juventud, Carlos V lo rodeó de un experimentado gobierno en el que figuraban Juan Tavera, Francisco de los Cobos, Fernando de Valdés, el duque de Alba y Juan de Zúñiga. Entre 1545 y 1547, sin embargo, este panorama se vio alterado por las sucesivas muertes de Tavera, Zúñiga y Cobos, así como por la partida de Alba hacia el Imperio, donde cosecharía la victoria de Mühlberg. Como consecuencia de estos acontecimientos, el único patrón que permaneció en su puesto fue Fernando de Valdés, nombrado entonces inquisidor general ${ }^{28}$. En aquella encrucijada, se desencadenaron diversos movimientos tendentes a la reorganización de las

\footnotetext{
${ }^{25}$ La trayectoria de Ruy Gómez de Silva en la Corte española (hasta 1554), en su camino ascendente hasta la privanza de Felipe II ha sido dibujada por Gonzalo Sánchez-Molero (1998). ${ }^{26}$ Las obras dedicadas al príncipe Felipe por entonces fueron la traducción castellana de la Institutio principis christiani de Erasmo (h. 1530) preparada por Bernabé de Busto y la Grammatica breuis ac perutilis (1532) de Lucio Marineo Sículo. Por entonces se publican también en la España renacentista importantes obras del discurso cortesano, tales como el Libro áureo de Marco Aurelio (1528) y el Relox de príncipes (1529) de fray Antonio de Guevara o la célebre traducción castellana de El cortesano de Castiglione debida a Juan Boscán (1534).

${ }^{27}$ La emergencia del círculo cortesano portugués en torno a las figuras de la emperatriz Isabel y el príncipe Felipe ha quedado descrita en Martínez Millán y De Carlos (1998: 34-38). Sobre los servidores de la Emperatriz ha escrito Labrador (2000a), mientras que la gestación y evolución de la Casa del príncipe Felipe (entre 1535 y 1546) ha recibido tratamiento particular en Fernández Conti (2000a).

${ }^{28}$ Para el conocimiento de la figura de Fernando de Valdés es imprescindible la obra de González Novalín (1968).
} 
facciones cortesanas. Así, la red de secretarios de Cobos pasó a ser controlada por su sobrino, Juan Vázquez de Molina, que pronto selló una fructífera alianza con Valdés para consolidar el grupo. Esta facción ejercería el dominio sobre la Corte española a comienzos de la década de 1550 como herederos de aquella política intransigente que había sido predominante en España desde $1530^{29}$.

A pesar de todo, durante la década de 1540 la educación del príncipe Felipe siguió dominada por preceptores humanistas. De hecho, en 1541 Zúñiga acentuó esta tendencia con el relevo de Martínez Silíceo, su primer maestro, y la incorporación de nuevos mentores como Juan Cristóbal Calvete de Estrella (discípulo de Hernán Núñez, el Comendador Griego), Honorato Juan (formado a la sombra de Juan Luis Vives) y Juan Ginés de Sepúlveda (el único que encarnaba el espíritu de la escolástica), a quienes se unió en 1543 el teólogo complutense Francisco de Vargas. Gracias a ellos, Felipe fue instruido en un amplio repertorio de materias que iban desde la teología a la medicina, pasando por la geografía y la historia ${ }^{30}$. Finalmente, Gonzalo Pérez, quien había crecido al amparo de Alfonso de Valdés, pasó a ejercer como su secretario personal, si bien se hallaba bajo la órbita de influencia del duque de Alba. A él se debe la traducción al castellano de la Ulixea de Homero (1550 y 1556), concebida en aquel contexto como un espejo de príncipes destinado a la formación del heredero ${ }^{31}$. El hecho de que en el entorno del joven Habsburgo se fuese consolidando una facción alternativa al grupo dominante se vio reforzado por su matrimonio con María Manuela de Portugal, a cuya sombra se incorporaron a la Corte española nuevos súbditos lusitanos que vinieron a reforzar el círculo cortesano portugués, debilitado tras la muerte de la emperatriz Isabe ${ }^{32}$. Aunque la princesa murió prematuramente como consecuencia del parto de su primogénito (julio de 1545), muchos de sus compatriotas permanecieron en

\footnotetext{
${ }^{29}$ Aquel período de transición, marcado por la muerte de los grandes patronos y la reorganización de las facciones cortesanas, puede conocerse a través de Martínez Millán y De Carlos (1998: 39-41).

${ }^{30}$ La educación del príncipe Felipe ha merecido la atención particular de Gonzalo SánchezMolero (2014).

${ }^{31}$ Sobre el proceso de preparación y la intención didáctica de la traducción de Gonzalo Pérez, remito al trabajo de Muñoz Sánchez (2017).

${ }^{32}$ Acerca de los servidores de María Manuela de Portugal en la Corte española, véase Labrador (2000b).
} 
Castilla para servir al infante don Carlos, quien se crio junto a otros miembros de la familia real, como las infantas María y Juana, hermanas menores del príncipe Felipe. Así, en torno a la Casa del Príncipe y la Casa de las Infantas (dividida en $1549)^{33}$ se consolidó un grupo de cortesanos que, debido a sus orígenes geográficos -portugueses en muchas ocasiones-, su mentalidad -más humanista y transigente- y su espiritualidad -entre ellos predominaba el recogimiento y el carisma de la Compañía de Jesús ${ }^{34}$-, se erigió el núcleo fundacional de la facción ebolista, que trataría de tomar las riendas de la Monarquía una vez consumada la sucesión al trono ${ }^{35}$.

A finales de 1547, una vez derrotados los protestantes alemanes, Carlos $\checkmark$ promovió la fundación de la nueva Casa de Borgoña del príncipe Felipe y su viaje de formación por Europa con objeto de que conociese a sus futuros súbditos. Para la regencia el Emperador contó entonces con la pareja formada por María y Maximiliano, desposados en el otoño de 1548. Al frente del gobierno quedaron Valdés y Vázquez de Molina, cabezas del partido imperial, al que poco más adelante se uniría el duque de Alba. En abierta oposición al mismo se fraguaba el partido del príncipe, cohesionado en torno al séquito del heredero y en el que militaban hombres de su máxima confianza, como Ruy Gómez de Silva, compañero de juegos desde la niñez ${ }^{36}$. Para aquel sector, el felicísimo viaje de Felipe por Europa (1548-1551) representó un éxito rotundo, pues lograron difundir entre sus súbditos la misma imagen de irenismo que Erasmo y sus

\footnotetext{
${ }^{33}$ La Casa de las infantas doña María y doña Juana ha sido estudiada por Ezquerra (2000). Sobre los servidores de doña Juana de Austria (origen y espiritualidad), véase Martínez Millán (2003).

${ }^{34}$ La espiritualidad de la Compañía de Jesús en sus primeros tiempos y su arraigo en la Corte española a través del círculo cortesano portugués y los miembros más jóvenes de la familia real ha sido estudiada por Martínez Millán (2012).

${ }^{35}$ La consolidación del círculo cortesano portugués en torno a los miembros más jóvenes de la familia real ha sido descrita por Martínez Millán y De Carlos (1998: 41-48).

${ }^{36}$ La división de la Corte española entre el partido imperial (Valdés y Vázquez de Molina) y el partido del príncipe (Ruy Gómez de Silva) durante la regencia de María y Maximiliano ha sido expuesta por Martínez Millán y De Carlos (1998: 49-51). En el entorno del príncipe, sin embargo, el duque de Alba, mayordomo mayor de su Casa de Borgoña, comenzó a crear una nueva red clientelar aprovechando la capacidad de influencia que el cargo le otorgaba (a ella pertenecía, por ejemplo, el secretario Gonzalo Pérez). Debido a su afinidad ideológica y a los intereses compartidos, Alba no tardó en aliarse con Valdés y Vázquez de Molina, dando lugar, ya en la década de 1550, al partido albista, cuyo enfrentamiento con el partido ebolista marcaría toda una época en la Corte española. Sobre ambas facciones ha escrito Maltby (1985: 88-113), quien deslinda con precisión sus respectivas señas de identidad.
} 
seguidores proyectasen en su día sobre Carlos $\mathrm{V}^{37}$. Con el regreso del príncipe Felipe a España en 1551 quedó constancia de que en su entorno había cuajado una facción que desde entonces pugnaría por acceder a las instituciones de la Monarquía ${ }^{38}$. El enfrentamiento entre estos dos grupos de poder, entre estas dos tradiciones políticas se hallaba, pues, listo para su desenlace, que no se alcanzaría hasta 1556.

\section{Un imperio en transición (1551-1559)}

Con el comienzo de la década de 1550 se inauguran unos años especialmente convulsos para la Monarquía, en los que la efímera supremacía alcanzada en Alemania tras la victoria de Mühlberg (1547) y los acuerdos de familia para la sucesión al trono imperial (1551) quedaron empañados por una serie de acontecimientos adversos que obligaron a Carlos $\mathrm{V}$ a abandonar precipitadamente suelo germánico y a desvincular las posesiones centroeuropeas de la herencia de Felipe. Tras estos sucesos, el nuevo equilibrio de fuerzas entre las dos ramas de los Habsburgo y la autonomía religiosa de los príncipes alemanes quedarían definitivamente confirmados. Aquella difícil encrucijada, sin embargo, tuvo su origen en Italia, donde Carlos V y Enrique II, nuevo rey de Francia tras la muerte de Francisco I en 1547, se disputaban los ducados de Piacenza y Parma. La reapertura de hostilidades entre las dos potencias hizo necesaria la recaudación de subsidios para la guerra, de manera que el príncipe Felipe fue enviado con urgencia a los reinos hispánicos para acometer personalmente la tarea, pues Maximiliano había abandonado precipitadamente España para la defensa de sus derechos sucesorios en Alemania. Mientras Felipe regresaba a la Península en septiembre de 1551, un importante contingente de tropas imperiales abandonaba territorio alemán camino de Italia, debilitando la posición del Emperador en el corazón de Europa.

Confiado por sus recientes triunfos y la publicación del Interim de 1548, Carlos V no calibró a tiempo el peligro que se cernía sobre sus intereses, pues

\footnotetext{
${ }^{37}$ El desarrollo y significado del felicísimo viaje ha sido analizado por Gómez-Centurión (2000).

${ }^{38}$ La configuración de la nueva Casa de Borgoña y el viaje de Felipe por Europa favorecieron la consolidación en torno a su persona de un grupo de leales servidores (el partido del príncipe) que pronto estaría en disposición de pugnar por el poder de la Monarquía reemplazando a los hombres de confianza del viejo Emperador, tal y como explica Fernández Conti (2000b).
} 
los príncipes alemanes se mostraban muy contrariados y hostiles a su causa debido a sus últimas maniobras, que alteraban gravemente la estructura territorial y el orden político del Imperio. En efecto, los pactos de familia habían propiciado otras decisiones complementarias que implicaban la efectiva escisión de Borgoña y los Países Bajos de aquel conglomerado -con objeto de vincularlos a la herencia patrimonial de Felipe-, así como la consideración del cetro imperial como un cargo hereditario, lo que minaba el poder de los príncipes electores. Por si fuera poco, parece que Maximiliano, recién llegado de España, alentó la insurrección de los príncipes, molesto ante la ambición de Carlos $V$ y descontento con el reparto. En ese contexto, los alemanes buscaron el apoyo de Enrique II, a quien compensaron su esfuerzo de guerra con los obispados de Metz, Toul y Verdún, cuya conquista y anexión a Francia fue consentida por sus aliados. Así las cosas, en la primavera de 1552 el Emperador se vio sorprendido en Innsbruck por el rápido avance hacia el sur de las tropas de Mauricio de Sajonia. Cortado el paso hacia Flandes por los franceses, Carlos V hubo de escapar precipitadamente de la plaza a través de los Alpes acompañado de un reducido séquito. Aquella deshonrosa huida constituyó una amarga jornada para el Emperador, que se veía hostigado por Enrique II en todos los frentes.

Mientras Carlos V recomponía su posición, Fernando acudió a la defensa de Hungría -una vez más amenazada por los turcos- con el apoyo de algunos príncipes rebeldes, como Mauricio de Sajonia, quienes cambiaron de bando y se comprometieron significativamente con la Corte de Viena en aquel momento crítico para el futuro del Imperio. De hecho, las relaciones entre Fernando y los príncipes alemanes eran miradas con sospecha por el Emperador, cuya posición en el tablero germánico parecía ya insostenible. Fue precisamente su hermano quien firmó el tratado de Passau -más tarde ratificado por Carlos V- con Mauricio de Sajonia en el verano de 1552. En él, además de sellar una alianza militar, se reconocía la igualdad entre el luteranismo y el catolicismo en los principados alemanes a partir de la fórmula cuius regio eius religio ${ }^{39}$, que

\footnotetext{
${ }^{39}$ Mediante esta fórmula, católicos y luteranos alcanzaron un acuerdo de compromiso en el Imperio por el que se reconocía a cada príncipe el derecho de implantar en sus dominios la confesión por él mismo adoptada. Esto constituyó un hito para la consolidación institucional de la Reforma, pues desde este momento dispusieron de las bases jurídicas necesarias para edificar las nuevas Iglesias evangélicas. En todo caso, es preciso señalar que no existió tolerancia
} 
quedaría definitivamente sancionada en la paz de Augsburgo (1555), momento en que dichas concesiones adquirieron forma constitucional en el Imperio. E último episodio de aquel conflicto se escenificaría en el asedio de Metz, cercada infructuosamente por las tropas imperiales en medio de un durísimo invierno que terminó por agotar las fuerzas y la moral del ejército. Entrado el año 1553, finalmente, el viejo Emperador, abatido y deteriorado, tomó el camino de los Países Bajos para atender la llamada de su regente, María de Hungría ${ }^{40}$. Desde allí dirigiría la guerra contra Francia y prepararía la sucesión al trono, que, en última instancia, no se consumaría hasta los años 1555 y 1556 . Este fue el desenlace de la política imperial de Carlos V, quien tras aquellos reveses dejaría los asuntos de Alemania en manos de Fernando. Después de treinta años de conflicto, había constatado en carne propia los peligros que la herejía entrañaba para la estabilidad política de sus reinos ${ }^{41}$.

Mientras todo esto sucedía, desde el otoño de 1551 Felipe se había situado al frente de la regencia de España rodeado de un nuevo grupo de cortesanos encabezado por Ruy Gómez de Silva que pugnaría en adelante por conquistar los resortes del poder al amparo del Príncipe. Este núcleo de servidores iría paulatinamente minando el patronazgo de Fernando de Valdés y de Vázquez de Molina, hombres experimentados en el gobierno de la Monarquía, pero afines a la figura del Emperador. Unos y otros hubieron de atender en este

religiosa ni en el mundo católico ni en el protestante, pues se consideraba que la homogeneidad en el sistema de creencias de los súbditos era imprescindible para garantizar el orden político. A uno y otro lado de la frontera religiosa, por tanto, hubo necesidad de definir con claridad una estricta ortodoxia y de articular los medios para imponerla desde la cúspide del poder. Estos fueron los mecanismos que propiciaron el proceso de confesionalización, que se extendió por Europa desde mediados del siglo XVI. Así lo explica Martínez Millán (2011: 133-152), quien aporta reflexiones teóricas sobre un concepto con el que se ha querido superar la clásica dicotomía entre Reforma y Contrarreforma.

${ }^{40}$ Este y no otro fue el "victorioso Emperador" -según reza la data del Lazarillo- que recibieron los españoles residentes en los Países Bajos a la altura de 1553. En aquel contexto se localizan las primeras ediciones de la obra plenamente documentadas (Amberes, 1553), tal y como ha demostrado Rodríguez López-Abadía (2016). En 1554, el libro se extiende por Castilla siguiendo la ruta del norte (Burgos y Medina del Campo) para llegar finalmente a Alcalá, donde se imprime ya un texto con interpolaciones. Todavía en 1554 una cuarta edición se registra en Amberes y, al año siguiente, la novela se ofrece ya junto a la Segunda parte de Lazarillo de Tormes (Amberes, 1555), también anónima, pero quizás salida de la misma pluma, según apuntan recientes estudios de estilometría: Rodríguez López-Vázquez (2018). Así las cosas, cabe preguntarse, ¿sería aquel el contexto de escritura del Lazarillo?, ¿sería su autor uno de aquellos españoles desplazados a los Países Bajos a comienzos de la década de 1550?

${ }^{4}$ Para un conocimiento más exhaustivo de aquel período de transición en el Imperio, véanse los trabajos de Lutz (1992: 101-109), Rodríguez Salgado (1992: 62-83) y Martínez Millán (2000b). 
tiempo las urgentes solicitudes de dinero que llegaban desde los Países Bajos, pues era imprescindible sufragar la guerra contra Francia. Desde el norte, Francisco de Eraso, secretario personal de Carlos V, incluso recomendaba una suspensión de pagos en España para atender estas obligaciones. Al tiempo, avanzado el año 1553, daba cuenta a Felipe de la debilidad de su padre, apartado por entonces de los asuntos de Estado a causa de su manifiesta incapacidad física y mental. Era acuciante, pues, la partida del príncipe hacia Bruselas para tomar las riendas del Imperio Habsburgo, que se enfrentaba entonces a numerosos peligros sin una cabeza firme y muy mermado económicamente. Dadas las circunstancias, Felipe dio un paso al frente y asumió una participación más directa en las tareas ejecutivas. Así, en el exterior, tras la captura de quince navíos españoles por los franceses, declaró la guerra al país vecino desde los reinos peninsulares; mientras, en el interior, fomentó el nombramiento de nuevos oficiales afines a su persona, tarea en la que resultó muy valiosa la colaboración de Eraso, cuya cercanía al partido del príncipe se hizo cada vez más evidente ${ }^{42}$.

La acuciante necesidad de fondos aceleró las negociaciones para la segunda boda de Felipe, para la que se escogió en 1553 la opción de María de Portugal. Al final de aquel verano, sin embargo, surgió la posibilidad de sellar un matrimonio más ventajoso con María Tudor, hija de Enrique VIII y de Catalina de Aragón, cuya candidatura al trono de Inglaterra se había impuesto a las de Lady Jane y María Estuardo tras la muerte de Eduardo VI. Este casamiento resultaba extraordinariamente ventajoso para todas las partes, pues mientras María Tudor apuntalaba su poder en las Islas, los Habsburgo lograban no solo el respaldo británico a corto plazo, sino que fomentaban la futura unión de Inglaterra y los Países Bajos -siempre bajo el cetro de un futuro descendiente de la pareja- y la consecuente desvinculación de aquellos reinos de la herencia Trastámara, que quedaría en manos del infante don Carlos. Esta jugada maestra en el tablero internacional dejaría definitivamente cercada a Francia -el gran proyecto de Fernando el Católico-, pues de consumarse la dinastía Habsburgo dominaría

\footnotetext{
${ }^{42}$ La trayectoria cortesana del secretario Francisco de Eraso ha sido reconstruida por De Carlos (1994).
} 
prácticamente todas sus fronteras. Conscientes de ello, Carlos V y María de Hungría, desde Flandes, apoyaron decididamente esta posibilidad. Las urgencias de los emisarios imperiales por cerrar el casamiento inglés, sin embargo, los condujeron a firmar unas cláusulas matrimoniales muy onerosas para los intereses de Felipe. De hecho, cuando el príncipe las conoció en enero de 1554 las rechazó frontalmente, pues limitaban en demasía su campo de actuación como rey consorte. A esas alturas, en todo caso, era ya tarde para retomar la opción portuguesa, de modo que se dispuso a preparar el séquito que lo acompañaría a las Islas Británicas y a organizar la regencia que habría de gobernar los reinos hispánicos en su ausencia.

A comienzos de 1554 la salud del Emperador mejoró notablemente y volvió a participar en las decisiones de Estado. Quedaba por resolver, no obstante, la cuestión de la regencia de España. Deseoso de dejar a sus espaldas un gobierno afín a su persona, el príncipe se decantó finalmente por su hermana menor, doña Juana de Austria, quien había enviudado el 2 de enero de 1554 tras la inesperada muerte de su esposo, el príncipe Juan de Avís. A pesar de que Valdés era preferido por el Emperador, Felipe forzó el regreso de doña Juana desde Portugal para que desempeñase el cargo, ya que confiaba plenamente en la fidelidad de la joven Habsburgo y en el núcleo de servidores que la rodeaban, pues su Casa se había erigido desde la década anterior en uno de los principales baluartes del círculo cortesano portugués en España. Con el fin de evitar nuevos desencuentros, Carlos sancionó la decisión del príncipe Felipe. Lo mismo sucedió con el nombramiento de los principales consejeros y gobernantes, escogidos por Felipe entre sus más leales servidores, pues deseaba partir hacia el norte dejando atrás un gobierno que le permitiese controlar de manera efectiva los reinos peninsulares -pertenecientes todavía a su padre- una vez que, con el abandono de la regencia, desapareciesen sus vínculos legales con España. La operación culminó con éxito y la mayor parte de puestos vacantes fueron ocupados por individuos afines a Ruy Gómez de Silva y al partido del príncipe, lo que limitó aún más el poder de Fernando de Valdés y de Vázquez de Molina, 
cuyo declive se hacía cada vez más evidente ante la inminente sucesión al trono y el empuje de la facción que contaba entonces con la confianza del heredero ${ }^{43}$.

El 20 de julio de 1554, finalmente, el príncipe Felipe desembarcaba en Inglaterra, lo que suponía su definitiva irrupción en la escena internacional. A pesar de sus esfuerzos de adaptación a los modos ingleses, un importante sector de la Corte de Londres se mostraba hostil a la injerencia de los españoles en los asuntos de Estado, pues esta amenazaría tanto su independencia política (en el marco del Imperio Habsburgo), como la propia supervivencia del protestantismo en aquel territorio. Como consecuencia de estas tensiones, no tardaron en surgir rivalidades en palacio entre la nobleza local y el grupo de servidores venido de España. Una vez celebrada la boda el 25 de julio, Felipe se mostraba ansioso por unirse al Emperador en los Países Bajos, más si cabe al conocerse la intensa campaña lanzada ese verano contra Flandes por Enrique II. Mientras tanto, desde Bruselas llegaban mensajes contradictorios que terminaron de desconcertar a Felipe, quien vivió meses de angustia en las Islas maniatado por las reticencias inglesas y frustrados sus deseos de paternidad a causa de la esterilidad de María Tudor, ya de edad avanzada. A pesar de todo, durante aquel período ejerció una intensa actividad política en dos ámbitos: la reorganización del dividido Consejo de Estado para que resultase funcional y operase en sintonía con la voluntad regia; y la restauración del catolicismo en Inglaterra para devolver el reino a la obediencia de Roma, lo que se logró finalmente tras superar muchas dificultades. Se inició entonces una cruenta represión contra los protestantes y muchos de sus líderes terminaron en la hoguera, como los obispos Ridley y Latimer, o el mismo Thomas Cranmer, arzobispo de Canterbury, a quien María responsabilizaba de la anulación del matrimonio de sus padres. Esta política de represión minó la popularidad de los monarcas y exacerbó todavía más el sentimiento antiespañol y anticatólico de los ingleses ${ }^{44}$. De hecho, durante los trece meses que permaneció en suelo británico -desde julio de 1554

\footnotetext{
43 Todas las circunstancias que precedieron al compromiso matrimonial con María Tudor y a la partida de Felipe hacia Inglaterra en julio de 1554 han quedado expuestas en Rodríguez Salgado (1992: 117-140). Sobre el ascenso del partido de Éboli durante el último período de regencia de Felipe, véanse Martínez Millán y De Carlos (1998: 51-56) y Fernández Conti (2000c: 250-252). ${ }^{44}$ Acerca de la restauración católica en Inglaterra y la labor ejercida allí por Bartolomé Carranza, véase el trabajo de Tellechea Idígoras (1964).
} 
a finales de agosto de 1555- el príncipe consorte no logró ser coronado y reconocido por el Parlamento ante las suspicacias de los nobles. Los problemas económicos y el (supuesto) embarazo de María Tudor lo retuvieron todavía en Inglaterra durante algún tiempo, pero la confirmación de que el anhelado sucesor no vendría al mundo lo animó a partir hacia los Países Bajos en el verano de 1555. A finales de agosto marcharía al encuentro de su padre dejando atrás a su segunda esposa, muy mermada psicológicamente como consecuencia de tantas presiones ${ }^{45}$.

El 25 de octubre de 1555 se celebró en Bruselas la ceremonia oficial por la que Carlos V abdicaba en su hijo Felipe y le cedía el cetro de los Países Bajos. Se iniciaba así un lento proceso de transición y traspaso de poderes que no culminaría hasta el año siguiente. Antes, a comienzos de 1554, Felipe había recibido ya las posesiones italianas con el fin de acudir a sus segundas nupcias en igualdad de condiciones que su prometida. Heredó entonces el reino de Nápoles (con la amenaza de turcos y franceses sobre Cerdeña) y el ducado de Milán (con el frente del Piamonte muy debilitado). Para el gobierno de Italia, Felipe deseaba la promoción de un hombre de su máxima confianza, el duque de Alba, quien, pese a las objeciones de Carlos V, fue nombrado virrey de Nápoles, gobernador de Milán y capitán general de todos los ejércitos de Italia en 1555. Alba debería procurar el mantenimiento de aquellos territorios gracias a su experiencia militar y hacer efectivo el traspaso de poderes en los feudos transalpinos ante los numerosos obstáculos puestos por el Emperador. Ese mismo año de 1555, Fernando ultimó con los príncipes alemanes los acuerdos de Augsburgo, cuyas cesiones en asuntos religiosos no fueron asumidas por la rama española de los Habsburgo por cuestiones de honor. A pesar de todo, Fernando fue apoyado en última instancia por Felipe para su elección imperial, pues ambos eran conscientes de que, tanto por razones prácticas como morales, la dinastía debía permanecer unida y colaborar estrechamente para enfrentarse a sus poderosos enemigos exteriores. La clausura definitiva de esta compleja transición escenificada en tierras flamencas aconteció el 17 de septiembre de

\footnotetext{
${ }^{45}$ Los numerosos avatares que jalonaron la estancia de Felipe II en la Inglaterra de María Tudor pueden conocerse, en el marco de su contexto internacional, por medio de Rodríguez Salgado (1992: 140-157), Fernández Conti (2000c: 252-259) y Parker (2010: 108-164).
} 
1556, cuando Carlos V y María de Hungría embarcaron hacia España. Felipe quedaba ya solo al mando de todos los territorios del Imperio Habsburgo, excepto el Franco Condado, que permanecería simbólicamente en manos de su padre. Pocas semanas después, el viejo Emperador se instalaría en Yuste, retiro desde el que no cesó de interferir en la regencia de doña Juana, cuyos objetivos políticos no coincidían exactamente con los suyos en numerosas cuestiones.

Pocos meses antes, la subida al solio pontificio de Paulo IV (1555-1559) había inaugurado un tiempo nuevo en Italia tanto por su acusada intransigencia religiosa como por su manifiesto apoyo a Francia. Siguiendo la estela de Clemente VII, albergaba el propósito de repartirse los territorios italianos con Enrique II una vez expulsados los Habsburgo de aquella zona de influencia. En esta encrucijada y ante la inminente ofensiva del francés, Alba necesitaba de cuantiosos recursos -unos 600.000 ducados- para sostener la campaña, cantidad que reclamó al gobierno de regencia por medio de Luis Barrientos. A la postre, nunca le serían ofrecidos más de 400.000 , que por su insuficiencia siempre rechazó. Desde la primavera de 1555, Alba se quejó de las maquinaciones de Ruy Gómez de Silva y Francisco de Eraso, a quienes acusó de entorpecer la llegada de recursos a Italia. Las pugnas faccionales por alcanzar la supremacía en la Corte de Felipe Il se desataron con motivo de aquel episodio, pues Alba inició una ofensiva en palacio para acabar con Eraso y situar en su puesto a Rodrigo de Dueñas, quien le había prometido un préstamo de 300.000 ducados. Sin embargo, el descubrimiento del plan permitió a Eraso reunir pruebas contra Dueñas que echaron por tierra su candidatura y dejaron en evidencia a su valedor. Mientras tanto, Paulo IV lanzaba un feroz ataque contra la aristocracia afín a España -los Sforza, los Colonna- que padeció la requisación de bienes y el encarcelamiento de muchos de sus miembros. Con este movimiento, trataba de destruir la base del poder hispano en la Península, pues, tras debilitarse la autoridad imperial al sur de los Alpes, Felipe II había reforzado su alianza con los potentados italianos para ejercer un control efectivo sobre el territorio a través de aquellas clientelas. Acto seguido, rota la tregua de Vaucelles (1556) después de un año, la ofensiva del duque de Guisa (y del ejército pontificio) en Nápoles terminó en triunfo para Alba (1557). Treinta años 
después del sacco, las tropas españolas se hallaban de nuevo a las puertas de Roma. Antes de asolar la ciudad, sin embargo, Álvarez de Toledo prefirió pactar con el papa Caraffa una paz que, paradójicamente, resultaría muy ventajosa para el Pontífice. Felipe II la aceptó (muy a disgusto) a comienzos de 1558, cuando la guerra en el norte era ya inminente y convenía cerrar otros frentes. A pesar de todo, Felipe supo rentabilizar tanto sus victorias militares como sus derrotas diplomáticas gracias a una buena campaña propagandística donde se mostraba como un rey generoso en la paz, fiel a sus aliados y respetuoso con la soberanía de los señoríos ajenos. Sea como fuere, el desenlace de aquel conflicto resultó positivo para la Monarquía Hispana, pues, como resultado de una política de concordias, logró afianzar las alianzas tradicionales de Carlos V (Génova, Saboya y Florencia), atraer a antiguos señoríos afines a Francia (Parma o Urbino), y resolver el asunto de los territorios italianos feudatarios del Imperio, como Milán, para cuya administración y defensa Felipe fue nombrado vicario general en ausencia de Fernando). Hacia finales de la década, tras los reveses en el norte, la posición de Francia en la región alcanzó un punto de gran debilidad que se reflejaría en el tratado de Cateau-Cambrésis (1559), donde definitivamente renunciaría a sus pretensiones en Italia ${ }^{46}$.

Durante aquellos años, sin embargo, el principal teatro de operaciones se hallaba en el norte. A comienzos de 1557 Francia era consciente de las debilidades de la Monarquía de Felipe II debido a sus problemas de financiación, a su distanciamiento de la Corte de Viena y al propio desprestigio del monarca, cuya imagen era la de un hombre apocado y pusilánime incapaz de comandar con la suficiente energía aquel vasto Imperio. Así las cosas, en enero de 1557 Enrique II rompió la tregua atacando infructuosamente Douai, en Flandes. A partir de ese momento, el rey español se planteó la posibilidad de reiniciar las hostilidades en el Piamonte, Milán o la frontera pirenaica, pero finalmente se decantó por concentrar sus esfuerzos en los Países Bajos, donde esperaba contar con el apoyo de Inglaterra. A pesar de su insistencia -incluso se personó en la Isla para formular sus reclamaciones- no lo consiguió, pues sus súbditos

\footnotetext{
46 Para el conocimiento de la política española en Italia durante la década de 1550 pueden consultarse los trabajos de Maltby (1985: 115-140), Rodríguez Salgado (1992: 210-254) y Rivero Rodríguez y Martínez Millán (2000).
} 
rechazaron una implicación directa en las guerras de los Habsburgo. En sentido contrario, tampoco Felipe respaldó a Inglaterra contra Escocia, donde María Estuardo -desposada en 1558 con Francisco, delfín de Francia- representaba una constante amenaza dadas sus aspiraciones al trono inglés en connivencia con los Valois. En aquella compleja coyuntura, las fuerzas españolas concentraron su ofensiva en la plaza de San Quintín, donde obtuvieron una memorable victoria sobre el ejército francés el 10 de agosto de 1557. Como contrapartida, en enero de 1558 Enrique II logró apoderarse de Calais, uno de los últimos enclaves británicos en el Continente. Durante los meses siguientes, ingleses y españoles fueron incapaces de colaborar en una contraofensiva que les permitiese recuperar la plaza debido a la desconfianza y la descoordinación que presidía sus relaciones. A pesar de todo, la victoria española en Gravelinas (13 de julio de 1558) situó a Felipe II en una posición de fuerza para afrontar las negociaciones de paz, que no tardarían en llegar ante el agotamiento de ambas potencias. El fallecimiento de María Tudor el 17 de noviembre de 1558, finalmente, dibujó un nuevo orden en la escena internacional, pues con su pérdida desaparecía también el principal vínculo de unión entre Inglaterra y la Monarquía Habsburgo. De inmediato, Isabel I, hija de Ana Bolena y Enrique VIII, la sucedió en el trono. Una de sus primeras medidas fue la restauración del protestantismo en Inglaterra (con el consiguiente desplazamiento de los católicos), si bien las buenas relaciones con España se mantuvieron todavía durante algún tiempo.

En aquel otoño de 1558, estancado el conflicto y sin apenas recursos para prolongarlo, España y Francia buscaron una paz duradera, que se firmó definitivamente el 3 de abril de 1559 en Cateau-Cambrésis. En virtud de aquel acuerdo, Francia quedaba en posesión de la plaza de Calais, así como de los tres obispados imperiales ocupados a comienzos de la década (Metz, Toul y Verdún), mientras que como contrapartida reconocía plenamente la hegemonía española en Italia. Como colofón de aquel tratado, se selló el compromiso matrimonial entre Felipe II e Isabel de Valois, hija de Enrique II, que como gesto de buena voluntad contribuiría a cerrar aquella década de enfrentamientos y a inaugurar un tiempo nuevo en Europa. La boda se celebró por poderes en París, 
el 22 de junio, actuando el duque de Alba en representación del monarca español. Durante los días siguientes se organizaron grandes festejos en la Corte, entre los que se incluyó -siguiendo la tradición caballeresca- un torneo. Allí caería mortalmente herido Enrique II por la lanza del conde de Montgomery, que tras penetrarle por un ojo le causó la muerte pocos días después, el 10 de julio de 1559, tras una terrible agonía. Francia quedaba en manos de su hijo, el joven Francisco II, quien, falto de experiencia, cedió la gobernación del reino a prominentes nobles como el belicoso duque de Guisa. Esta sería la tónica dominante en Francia durante la segunda mitad del siglo XVI, pues los numerosos hijos de Enrique II y Catalina de Médici irían muriendo uno tras otro siendo todavía menores de edad. Mientras, el reino se desangraba en cruentas guerras de religión donde la alta aristocracia ejerció un papel preponderante en los distintos bandos. Felipe II, a pesar de la debilidad del reino vecino, prefirió entonces mantener la paz y preparar su regreso a la Península. Para ello, resultaba esencial organizar la regencia de los Países Bajos, que puso en manos de Margarita de Parma, su hermanastra. Junto a ella, el control efectivo de aquellas provincias descansaría sobre los hombros del experimentado Antonio Perrenot, el futuro cardenal Granvela, y de un nutrido grupo de oficiales españoles que ocuparon los puestos clave de la administración para garantizar la autoridad de la Corona. Apoyados por una importante guarnición de veteranos, muy pronto tendrían que hacer frente a las reivindicaciones de la nobleza local (Orange, Egmont y Hornes), que desde el Consejo de Estado canalizó el descontento neerlandés ante la imposición de una férrea política dictada desde Madrid y ejecutada por Granvela. Cumplidos estos trámites, Felipe desembarcó por fin en España a finales de aquel verano, cuando su presencia resultaba ya imprescindible en los reinos peninsulares ante el acoso del Islam en el Mediterráneo y el descubrimiento de focos luteranos en Sevilla y Valladolid.

\section{La defensa de España en el Mediterráneo}

Para sostener todas estas campañas, Felipe contó siempre con el respaldo de España, que, a diferencia de los reinos del norte, contribuyó con fidelidad a la causa imperial. Gracias a la eficacia de doña Juana y su gobierno de regencia, 
en efecto, durante aquellos años se enviaron a Flandes ingentes cantidades de dinero desde la Península destinadas a sufragar los gastos de guerra. En ese contexto, las acuciantes necesidades económicas obligaron a adoptar graves decisiones, como el embargo de los metales preciosos traídos por la flota de Indias en 1556, la reestructuración de la deuda (mediante préstamos forzosos obtenidos de los mercaderes bajo amenaza de embargo), y la centralización de la hacienda real a través de factores que negociaban directamente en nombre del rey con los banqueros en todos los rincones de la Monarquía. Con el mismo afán recaudatorio, Felipe II obligó a los obispados y arzobispados españoles a prestar dinero extraído de sus rentas eclesiásticas a la Monarquía. Este procedimiento excepcional debía ser aprobado por el Papa y perdía su vigencia con el cambio de pontificado; además, solo estaba justificado si su fin era sufragar la guerra contra el infiel, no contra otro rey cristiano. De ahí que Paulo IV -enemigo declarado de España- derogase aquellos préstamos aprovechando su ascenso a la silla de Pedro en 1555. Igualmente, la resistencia fue notable en varias diócesis, como la de Toledo, donde el arzobispo Martínez Silíceo entorpeció en lo posible estas operaciones. En otros casos, las enemistades personales se mezclaron con estos asuntos, como ocurrió en el arzobispado de Sevilla, a cuya cabeza se hallaba Fernando de Valdés, que fue forzado a prestar cien mil ducados a la Corona por instigación de Bartolomé Carranza, enemigo del inquisidor general.

Mientras todos estos recursos fluían hacia el norte, los reinos peninsulares tenían sus propios problemas exteriores, entre los que destacaba por encima de todos la amenaza del Islam. En efecto, la situación en el norte de África se había complicado sobremanera en las últimas décadas a causa de la insuficiente atención prestada al frente mediterráneo por parte de la Monarquía, que lo consideraba secundario con respecto al norte de Europa. Así las cosas, si tras la conquista del reino de Granada fueron tomados varios enclaves estratégicos en el Magreb que apuntalaron las defensas de España, poco a poco esas plazas fuertes y presidios fueron cayendo debido al empuje musulmán, de manera que la piratería en el mar y el saqueo de las costas peninsulares se hicieron cada vez más frecuentes conforme avanzaba el siglo XVI. En dicha secuencia, tuvo 
especial trascendencia la caída de Argel en manos de los Barbarroja (1516), ciudad emblemática que desde entonces resistiría los embates españoles destinados a desmantelar aquel refugio de piratas y corsarios berberiscos. Por si fuera poco, desde 1529 Argel se convirtió en base de operaciones de la flota turca para sus acciones en el Mediterráneo central y occidental, pues el auxilio de los otomanos resultaba imprescindible para el mantenimiento de la plaza frente al poder del Imperio Habsburgo. Llegado el año 1550, la expansión del renacimiento morabita acentuó el extremismo religioso de los pueblos musulmanes de la zona, que por entonces se consagraron a la guerra santa contra el infiel en consonancia con los postulados más radicales de la Sublime Puerta. Esta reorganización del mundo islámico representaba sin duda una grave amenaza para la seguridad de España, cuya vulnerabilidad se hacía todavía más evidente a causa de las populosas comunidades moriscas -aún mal asimiladas a mediados de la centuria- que conservaban casi inalterables sus señas de identidad y su forma de vida en comarcas interiores de Aragón, Valencia y el antiguo reino de Granada. Como no podía ser de otra forma, Francia también jugó sus cartas en el Mediterráneo -siempre en perjuicio de España y de sus aliados tradicionales- a través de sus reiterados pactos con el Turco, que, tras ser renovados por Enrique II, le permitieron arrebatar Córcega a los genoveses en 1553 con el apoyo de tropas berberiscas y otomanas. Todas estas circunstancias, en suma, incrementaron extraordinariamente -a ojos del gobierno de regencia- el peligro de una invasión musulmana a mediados de la década de 1550, tal y como se colige de los alarmantes avisos enviados a Felipe desde España durante su estancia en los Países Bajos ${ }^{47}$.

Se trataba en gran medida de un problema de perspectiva acerca de las prioridades de la Monarquía: mientras Felipe II lo subordinaba todo a su lucha contra Francia en el frente flamenco y en Italia, donde se jugaba su honor y la hegemonía en Europa, el gobierno de doña Juana consideraba más urgente el fortalecimiento de las defensas interiores y el mantenimiento de los presidios en el norte de África para sacudirse el acoso musulmán. De ahí que, desde la

\footnotetext{
47 Puede obtenerse una visión general de la situación de la Monarquía Hispana en el Mediterráneo durante el reinado de Carlos V por medio de los trabajos de Sola (1988), Bunes Ibarra (2000, 2004, 2011 y 2016) y Rivero Rodríguez (2013).
} 
distancia, los remedios que el soberano sugiriese fueran los siguientes: para controlar a los moriscos del interior, planteaba un reforzamiento de la autoridad eclesiástica e inquisitorial que ayudase a reprimir la herejía; frente a los corsarios berberiscos alentaba una estrategia de autodefensa que recaería sobre los hombros de las poblaciones costeras y de los mercaderes; contra la flota turca, en fin, confiaba en una eventual intervención de las galeras estacionadas en Italia, que habrían de frenar su avance hacia el oeste. Frente a este programa de actuación -que apenas acarreaba costes para la Monarquía- la regencia planteaba desde España una política mucho más agresiva destinada a avanzar posiciones en el Magreb y a desmantelar los puertos desde los que se lanzaban las campañas berberiscas contra la Península y el Archipiélago Balear. Ante esta disparidad de criterios y el constante abandono por parte de la Corona, las guarniciones de los presidios norteafricanos se hallaban diezmadas y desmoralizadas. Esto explica la rápida caída de Bujía (1555), que apenas opuso resistencia a la flota turca llegada desde Constantinopla. Un año después, en 1556, Orán se salvó milagrosamente de otro asedio semejante. Felipe, confiado, desplazó entonces algunos de aquellos recursos hacia el norte para auxiliar en la guerra contra Francia. Entrado el año 1557, sin embargo, la situación se tornó favorable para los españoles, pues el conde de Alcaudete recibió refuerzos en Orán, mientras el mundo musulmán se desangraba en luchas intestinas que debilitaron la posición de Argel y la pusieron al alcance de la Monarquía Hispana. Así lo explicó el propio Alcaudete ante el gobierno de regencia en el verano de 1557. A pesar de la negativa de Felipe II a emplear nuevos recursos en el Mediterráneo, desde Valladolid se aprobó la ofensiva en el norte de África ante la insoportable presión de los musulmanes, que por entonces saquearon Ciudadela (Menorca) y sembraron el terror en el estrecho de Gibraltar con veinticinco naves corsarias. El ejército de diez mil hombres que debía recuperar Bujía y Argel, sin embargo, sufrió la terrible derrota de Mostaganem a finales de agosto de 1558, si bien Orán pudo mantenerse. Ante este fracaso, las autoridades españolas volvieron los ojos al interior con el fin de atenuar la 
amenaza que representaban las comunidades moriscas, lo que provocó nuevos conflictos sociales y favoreció a la postre el avance de la intransigencia ${ }^{48}$.

Los hechos a que nos referimos acontecieron en Aragón, donde la autoridad de la Monarquía estaba en entredicho desde 1556. En efecto, en tal fecha el conde de Francavilla, virrey castellano en Aragón (y a la sazón suegro de Ruy Gómez de Silva), hubo de huir de Zaragoza ante un levantamiento popular donde los insurrectos esgrimían los fueros del reino para justificar su rebeldía, motivada por la severidad de la justicia real. Como consecuencia de este vacío de poder, Aragón no contribuiría en los siguientes años a sufragar los gastos de la guerra en Flandes. La situación no podía ser más caótica: a la amenaza exterior de franceses y turcos se unía la rebelión fuerista contra la Corona (Felipe no había sido jurado todavía por las Cortes), el conflicto entre la aristocracia terrateniente y las ciudades y, finalmente, las pugnas faccionales en el seno de la nobleza. Fue precisamente esta división interna -unida a la falta de liderazgo- la que impidió que la resistencia a la autoridad de la Corona se convirtiera en una rebelión organizada que pusiese en juego la soberanía del reino. En esta encrucijada, los postulados más radicales se impusieron finalmente en la Corte, lo que motivó la adopción de una política beligerante tras haber ensayado ciertas medidas de distensión, como la desactivación de la Inquisición en tierras aragonesas. Así, en diciembre de 1558 se aprobó el edicto de desarme de los moriscos de Aragón, cuyos movimientos quedaban también limitados. Con ello trataba de impedirse un supuesto alzamiento, si bien tras estas medidas parecía esconderse también el propósito de limitar el poder de la nobleza local, que empleaba aquellas comunidades como verdaderos ejércitos privados para la defensa de sus intereses frente a la injerencia de cualquier autoridad externa ${ }^{49}$. Ante la ofensiva de la Corona, la aristocracia reaccionó fulminantemente y convocó de manera ilegal reunión de Cortes para el 6 de

\footnotetext{
48 La secuencia de acontecimientos vivida en el Mediterráneo a lo largo de la década de 1550 ha sido narrada, en el marco de su estudio general, por Rodríguez Salgado (1992: 395-429). Sobre la derrota de Mostaganem, véase también Vincent (2018).

${ }^{49}$ Conforme explicó Carrasco Urgoiti (1972), aquel debió ser el contexto de escritura del primer Abencerraje (versión Crónica), cuyo anónimo autor servía por entonces a Jerónimo Jiménez de Embún - tal y como se deduce de los preliminares-, miembro de la nobleza aragonesa en cuyas posesiones patrimoniales se asentaba una importante comunidad morisca dedicada al cultivo de la tierra en un clima de tolerancia y convivencia.
} 
enero de 1559. Sin embargo, las diferencias internas y el clima de violencia que rodeó aquellas reuniones obligó a su disolución entrado el mes de febrero sin que se hubiese alcanzado ningún acuerdo. Finalmente, en el verano de aquel mismo año, cuando la llegada de Felipe a la Península era ya inminente, el conde de Francavilla regresó a Zaragoza como muestra elocuente de la restauración del poder y el prestigio real. De este modo se cerraban tres años de rebelión en Aragón durante los que el gobierno de regencia y el ausente Felipe se mostraron impotentes para reconducir la situación ${ }^{50}$. En cualquier caso, los reinos de la Corona de Aragón, gracias a sus fueros y jurisdicción particular, se mantuvieron todavía relativamente a salvo de la creciente injerencia del poder monárquico y del imparable avance de la intransigencia religiosa que se padecían por aquellos días en Castilla. Esto propició que algunos súbditos, como Jorge de Montemayor, buscasen acomodo a finales de la década en tierras levantinas, donde encontraron sosiego y protección entre su más distinguida aristocracia ${ }^{51}$.

\section{La regencia de doña Juana de Austria (1554-1559)}

Para comprender el trasfondo ideológico que motivó estos acontecimientos y reorientó la política española en las postrimerías de aquel período de transición, no obstante, conviene analizar con detalle lo sucedido en la Corte de la Monarquía durante la regencia de doña Juana de Austria (1554-1559), donde se libró una cruenta disputa faccional entre el emergente partido de Éboli (evolución del partido del príncipe) y el partido imperial (con Valdés y Vázquez de Molina a la cabeza), que se resistía a perder su preeminencia ${ }^{52}$. Así, mientras Ruy Gómez de Silva y Francisco de Eraso controlaban desde el entorno de Felipe II la mayor parte de los nombramientos y el curso de las finanzas del Imperio, en Valladolid

\footnotetext{
50 Una narración sucinta de aquellos hechos se ofrece en Rodríguez Salgado (1992: 429-441). Para un conocimiento más profundo del trasfondo social y político de las revueltas aragonesas, véase también Colás y Salas (1982).

${ }^{51}$ A su regreso de Flandes, Jorge de Montemayor (cuya obra devota sería condenada por entero en el índice de Valdés) se cobijó en casa de Juan Castellá de Vilanova, señor de las baronías de Bicorb y Quesa, a quien, agradecido, dedicó La Diana, impresa en Valencia en torno a 1559. Al respecto, véase Torres Corominas (2012: 1364-1369).

52 La lucha de facciones librada en la Corte de Valladolid durante la regencia de doña Juana de Austria, así como la espiritualidad jesuítica predominante en su círculo más íntimo, ha sido estudiada por Martínez Millán y De Carlos (1998: 59-66) y García Hernán (1999: 139-164). Para una visión panorámica (humana, intelectual y política) de aquella etapa, véase también Sanz Ayán (1998).
} 
la princesa vivía rodeada de un séquito de servidores hispano-portugueses cuya forma de vida era más propia de un convento que de un palacio. La permanencia en su entorno de aquellos cortesanos no podía extrañar, pues doña Juana conservó durante aquella etapa fuertes vínculos con el país vecino, que se estrecharon aún más si cabe tras la muerte de Juan III en 1557, lo que convirtió a su hijo don Sebastián en heredero del trono portugués y a ella misma en excelente candidata para ocupar la regencia durante su minoría. En lo que respecta a su religiosidad, es preciso señalar que su intensa devoción la animó a ingresar en la Compañía de Jesús en el verano de 1555 bajo la dirección de Francisco de Borja y del padre Araoz ${ }^{53}$. Desde entonces, adoptó sus votos y costumbres y contribuyó con su ejemplo a que otros aristócratas y eclesiásticos favoreciesen también a los jesuitas. A la vista de su compromiso personal, a partir de esta época doña Juana se erigió en protectora de las corrientes religiosas tendentes al recogimiento y a una fe vivencial-aquellas que eran ya miradas con recelo por la Inquisición- $y$, de hecho, fue dedicataria de numerosas obras de devoción que revelan la existencia en torno a su persona de un círculo literario conformado por autores espirituales que, en su mayoría, tendrían problemas con el Santo Oficio llegado el año $1559^{54}$. No cabe duda, por consiguiente, de que la presencia de doña Juana al frente de la regencia favorecía al partido de Éboli, entre cuyos miembros se había criado y cuya espiritualidad compartía, de manera que cuando su cargo y su gobierno fueron ratificados en 1556, una vez consumada la sucesión al trono, quedó apuntalado el poder de aquella facción, pues controlaba los principales centros de decisión de la Monarquía por medio de Ruy Gómez de Silva, Francisco de Eraso y la propia Juana de Austria ${ }^{55}$. A pesar de todo, conforme a las instrucciones dejadas por Felipe en 1554 antes de su partida, Vázquez de Molina estaba facultado para intervenir en los negocios del Consejo Real, de Cámara, Hacienda, Cruzada y

\footnotetext{
${ }^{53}$ La figura de Francisco de Borja, quien ejerció durante años como director espiritual de doña Juana de Austria, puede ser conocida a través de García Hernán (1999).

${ }^{54}$ El círculo literario conformado en torno a la princesa Juana ha sido analizado por Bataillon (1952) y Torres Corominas (2008). A él pertenecieron, entre otros, Francisco de Borja, fray Luis de Granada o Jorge de Montemayor. Sobre este último, véase también Torres Corominas (2012). ${ }^{55}$ La gestación y evolución histórica del partido de Éboli merecieron la atención particular de Martínez Millán (1992). Sobre las relaciones de doña Juana de Austria con aquella facción, véase también Martínez Millán (1994a).
} 
Órdenes, mientras Fernando de Valdés mantenía el control sobre el Consejo de Inquisición, si bien su pérdida de influencia se acusaba incluso en la Suprema. La presidencia del Consejo Real, por su parte, fue ocupada sucesivamente por los ebolistas Juan de Vega (1557) y el marqués de Mondéjar (1558), mientras las Casas de doña Juana y el príncipe Carlos, en la misma línea, quedaron bajo la órbita de influencia de Ruy Gómez de Silva, cuya eficacia en la recaudación de fondos para la guerra no hizo sino reforzar su privanza.

En el marco de aquella soterrada pugna faccional, la estrella de Fernando de Valdés fue progresivamente declinando en palacio a lo largo de la década de 1550 como consecuencia de su feroz oposición al partido de Éboli y a todas aquellas corrientes de espiritualidad que, dentro del catolicismo, eran herederas del humanismo cristiano, perseguían la pureza y sencillez evangélicas o se internaban por la escondida senda del recogimiento. Fruto de esta actitud beligerante e intransigente tomó decisiones que perjudicaron a la propia Monarquía, como la denegación del dinero solicitado a su arzobispado para sostener la guerra en Flandes. Al tiempo, se enemistó con Eraso y preparó en secreto la boda de su sobrino sin contar con el beneplácito del monarca. Todos estos errores provocaron su caída en desgracia, de manera que Felipe, entrado el año 1557, le ordenó regresar a Sevilla. Se hallaba ya de camino hacia su arzobispado cuando encontró la ocasión propicia para rehacerse y lanzar una terrible contraofensiva destinada a desacreditar a sus enemigos políticos, a demostrar la pertinencia de sus postulados intransigentes y a restaurar su preeminencia en la Corte. Dicha ocasión se la brindó el descubrimiento de diversos focos luteranos en Sevilla y Valladolid, prueba evidente de los peligros que acarreaba una política religiosa tolerante y benevolente. Así las cosas, con aquellos ejemplos en la mano y haciendo uso de su autoridad como experimentado inquisidor y hombre de Estado, trató de persuadir al joven monarca de que aquellos servidores en los que tanto había confiado desde el inicio de su reinado practicaban una religiosidad heterodoxa que no le permitiría frenar el avance del protestantismo en España. Las noticias que llegaban del extranjero no hacían sino confirmar sus argumentos, pues en el norte de Europa las Iglesias reformadas se hallaban en pleno proceso de consolidación y 
expansión tras la paz de Augsburgo (1555), de manera que estas ramificaciones peninsulares de la herejía debían ser consideradas como brotes tempranos de aquella misma pestilencia. En estas circunstancias, Valdés pudo regresar a la Corte de Valladolid para ocuparse personalmente del asunto, de modo que recuperó la iniciativa política en la primavera de 1558. En Sevilla, la causa de los protestantes se puso en manos del obispo de Tarazona, Juan González Munébrega, que actuó entonces como inquisidor supernumerario ante la necesidad de reforzar el tribunal hispalense del Santo Oficio. Como leal servidor de Valdés, aplicó una feroz política de represión que daría lugar a los cuatro autos de fe celebrados a orillas del Guadalquivir entre 1559 y 1562. Así que la persecución desatada contra los luteranos y calvinistas españoles -más allá del celo religioso- escondía también una clara intención política, pues propició la reacción del partido imperial contra los ebolistas, quienes disfrutaban de la gracia real y se disponían a dominar la Corte al amparo de Felipe II. Para ello, no dudaron en instrumentalizar la herejía en su beneficio, ya que magnificaron los hechos, sobreactuaron para promover un clima de inseguridad generalizado y se aplicaron con una severidad inusual en los procesos inquisitoriales con objeto de acreditar (ante el Rey y sus súbditos peninsulares) que la amenaza del protestantismo se cernía dramáticamente sobre España ${ }^{56}$.

Al margen de estas maniobras, lo cierto es que aquellos focos de espiritualidad evangélica recientemente descubiertos en Sevilla y Valladolid constituían un importante salto cualitativo con respecto a lo vivido hasta entonces en los reinos hispánicos. En efecto, antes de la década de 1550 las actuaciones contra el luteranismo al sur de los Pirineos se habían reducido a la interceptación de libros heréticos introducidos clandestinamente en la Península y a la celebración de contados procesos inquisitoriales donde por lo general fueron encausados súbditos extranjeros, marineros o mercaderes las más veces ${ }^{57}$. Por lo que se refiere a luteranos propiamente españoles, apenas tenemos noticia de algunos casos aislados protagonizados por ciertos individuos que, debido a su oficio o actividad intelectual (eran comerciantes o estudiantes universitarios),

\footnotetext{
${ }^{56}$ La penetrancia y represión del luteranismo en España antes de 1550 pueden conocerse a través de los trabajos de Redondo (1965), Thomas (2000 y 2001) y Boeglin (2016).

${ }^{57}$ Así lo afirman González Novalín (1968: I, 177-179 y 287-299) y Huerga (1988: 34-43).
} 
tuvieron contacto directo con las ideas de la Reforma en los países del norte. Muchos de ellos no regresaron jamás a España y desarrollaron su actividad intelectual fuera de nuestras fronteras, como fue el caso de Francisco de Enzinas, activo difundidor de las ideas de Lutero y Calvino y traductor del Nuevo Testamento (1543) a partir de la versión griega de Erasmo ${ }^{58}$. Al margen de estos episodios, el primer grupo de protestantes españoles verdaderamente cohesionado fue el descubierto en Sevilla ${ }^{59}$. Según todos los indicios, tuvo su caldo de cultivo en la predicación y labor intelectual desarrollada desde la década de 1540 por hombres como el doctor Egidio o el doctor Constantino, vinculados a la catedral hispalense. Ambos, sin ser protestantes, sino reformadores dentro del catolicismo, esgrimieron en su labor pastoral doctrinas como la justificación por la fe o la exaltación de los méritos de Cristo -siempre en los límites de la heterodoxia- que, junto con actitudes como el desprecio de las ceremonias exteriores, calaron hondamente entre algunos de sus feligreses. Por ello, Egidio fue procesado por la Inquisición entre 1549 y 1552 y a la postre obligado a abjurar públicamente; mientras Constantino sería detenido en agosto de 1558 tras dos décadas de intensa actividad literaria. Un año después, todos sus libros pasarían a engrosar el Índice de 1559 mientras su autor permanecía en las cárceles de la Inquisición, donde moriría en febrero de 1560. Los dos, en fin, después de su fallecimiento, serían quemados en efigie en el auto de fe celebrado en Sevilla en diciembre de 1560, cuando el Santo Oficio los vinculó a los protestantes convictos y confesos que allí fueron expuestos a la vergüenza pública o ejecutados ${ }^{60}$.

Este grupo sevillano había sido descubierto tres años antes, en octubre de 1557, cuando Juan Ponce de León, hijo del conde de Bailén, y Julián Hernández, Julianillo, fueron detenidos por el tráfico de libros prohibidos impresos en Ginebra, que después distribuían por la capital hispalense. Este

\footnotetext{
58 La presencia de estudiantes españoles en Lovaina en la década de 1550 fue analizada por Tellechea Idígoras (1963), mientras que la figura de Francisco de Enzinas ha merecido el estudio particular de Bergua (2006).

59 Una visión general de los acontecimientos vividos en España tras el descubrimiento de los focos luteranos de Sevilla y Valladolid se halla en González Novalín (1979).

${ }^{60}$ Sobre los reformadores sevillanos, véanse las páginas dedicadas al movimiento por Bataillon (1966: 522-545) y Huerga (1988: 44-57). Sobre Constantino, véase además Nieto (1997: 217269 y 349-362) y sobre Egidio, Redondo (2001).
} 
hecho había estado precedido por la huida al extranjero de doce frailes del monasterio de san Isidoro del Campo, entre los que se hallaban Cipriano de Valera y Antonio del Corro, que tras colgar la cogulla partieron hacia territorio calvinista. Allí fueron recibidos por un exiliado sevillano, Juan Pérez de Pineda, ardiente partidario de la Reforma, que era precisamente quien suministraba a Julianillo aquella peligrosa mercancía ${ }^{61}$. El caso supuso un gran escándalo, que fue en aumento cuando, a comienzos de 1558, la Inquisición tuvo conocimiento de los conventículos luteranos del norte de Castilla. Este segundo foco había surgido algunos años antes en torno a la figura de don Carlos de Seso, caballero veronés de noble estirpe que introdujo en España las doctrinas criptocalvinistas aprendidas en Italia. Seso fue corregidor de Toro entre 1554 y 1557, donde comenzó a predicar entre un reducido grupo de seguidores del que formaban parte Pedro Cazalla, párroco de Pedrosa, y el bachiller Herrezuelo. Ganados para la causa, Cazalla y Herrezuelo difundieron estas ideas entre algunos vecinos de Toro y Zamora aprovechando su formación intelectual. No obstante, cuando el protestantismo castellano cobró verdadero cuerpo fue cuando penetró en Valladolid a través de la casa de Leonor de Vivero, madre de los Cazalla, y desde allí se extendió a varios centros religiosos y nobiliarios de la ciudad, como el monasterio de Belén o la casa de la marquesa de Alcañices (de quien era hija Ana Enríquez) gracias a sus múltiples relaciones sociales y al intenso proselitismo ejercido por los hermanos Agustín Cazalla y Francisco de Vivero ${ }^{62}$. El descubrimiento de estos focos, en suma, de los que formaban parte decenas de personas -algunas muy próximas a la princesa Juana- provocó la virulenta reacción de Valdés, que escribió a Carlos V, retirado en Yuste, para informarle sobre la gravedad del asunto. El Emperador, a la luz de la experiencia vivida en Alemania, solicitó de inmediato a la regente -en carta fechada el 25 de mayo de 1558- el máximo rigor en la represión de la herejía, pues resultaba esencial para la conservación de la paz y la estabilidad de los reinos hispánicos. De ahí que, anticipando los postulados que presidirían la época del confesionalismo, Carlos $\mathrm{V}$ animase a su hija a tratarlos como "sediciosos, escandalosos, alborotadores e

\footnotetext{
${ }^{61}$ La historia de los luteranos de Sevilla ha sido reconstruida por Boeglin (2005).

62 El proceso seguido contra los luteranos de Valladolid entre 1558 y 1559 puede ser conocido en todos sus detalles a través de Alonso Burgos (1983).
} 
inquietadores de la república, y que tenían fin de incurrir en caso de rebelión por que no se puedan prevaler de la misericordia". En consecuencia, mandaba que "ipso facto fuesen quemados y confiscada su hazienda"63. Con el viento a favor, Valdés aprovechó la ocasión para solicitar a Paulo IV poderes extraordinarios que le permitiesen procesar a cualquier dignidad eclesiástica española sospechosa de herejía. Con el consentimiento papal y la aquiescencia de Felipe Il y doña Juana, el inquisidor general halló entonces el camino expedito para lanzarse contra sus enemigos políticos, reprimir implacablemente la herejía y señalar en el Catálogo de libros prohibidos de 1559 las nuevas fronteras de la heterodoxia. Como resultado de todo ello, se organizaron grandes autos de fe en Valladolid (mayo y octubre de 1559) y Sevilla $(1559,1560$ y 1562) tras los que el protestantismo quedaría prácticamente erradicado en España.

Todos aquellos sucesos, sin embargo, tuvieron una repercusión más amplia y duradera en la cultura española, pues permitieron a los sectores más intransigentes avanzar posiciones en la Corte y convencer a Felipe II de la necesidad de un cambio de política para atajar de raíz el problema religioso ${ }^{64}$. En esa línea, una de las primeras medidas adoptada para fortalecer los mecanismos de control sobre la actividad intelectual y la circulación de las ideas fue la aprobación de una nueva pragmática sobre la impresión de libros, publicada el 7 de septiembre de 1558, que vino a regular los procedimientos burocráticos necesarios para estampar cualquier texto en Castilla. La nueva reglamentación seguía los pasos de la pragmática de 1502, dada en tiempos de los Reyes Católicos, por la que se establecía la necesidad de censura previa para la concesión de licencias de impresión, si bien a comienzos del siglo XVI se permitió que este escrutinio se llevase a cabo de manera descentralizada. En 1554 se estableció que estas licencias solo pudiesen ser concedidas por el Consejo de Castilla, con el fin de evitar fisuras y ejercer una vigilancia más

\footnotetext{
${ }^{63}$ Carta de Carlos V a doña Juana de Austria, fechada a 25 de mayo de 1558, transcrita en Kamen (1999: 95).

${ }^{64} \mathrm{La}$ quiebra de la transigencia ideológica y religiosa han sido explicadas, en su contexto cortesano, por Martínez Millán y De Carlos (1998: 66-71). Las numerosas medidas adoptadas por la Monarquía para frenar el avance de la herejía y ejercer un férreo control sobre la cultura han sido después sintetizadas por Fernández Terricabras (2018), quien repasa las decisiones adoptadas para reforzar el poder y la eficacia de la Inquisición, regular la impresión y circulación de libros y vigilar la enseñanza universitaria, entre otras iniciativas.
} 
estrecha desde las altas instituciones de la Monarquía. En 1558, finalmente, al calor de los acontecimientos descritos y del clima de vulnerabilidad que se extendió por España, la nueva pragmática -destinada a reprimir la herejía, como se advertía explícitamente en su prólogo- obligaba a la presentación de un original (manuscrito o impreso) al Consejo de Castilla, que, tras ser aprobado por un censor y rubricado por un escribano de la Cámara, podía pasar a la imprenta. No obstante, una vez en letras de molde, el texto debía ser cotejado con el original aprobado con el fin de evitar modificaciones de última hora. Solo así se completaba el proceso burocrático y el libro se hallaba ya en disposición de circular libremente conforme a las disposiciones legales. De este modo, el Consejo de Castilla realizaba una primera criba que impedía la impresión de textos heréticos, inmorales o sediciosos. Como medidas complementarias, la venta de libros estampados fuera del territorio castellano requería igualmente de la preceptiva licencia del Consejo Real, como también era necesaria su aprobación para la comunicación o lectura de textos manuscritos concernientes a Sagrada Escritura, doctrina o religión ${ }^{65}$.

La Inquisición, en todo caso, no intervenía en estos trámites iniciales ni expedía licencias de impresión -esto es, no realizaba juicios a priori-, pues se reservaba la posibilidad de condenar una obra y prohibir su tenencia y lectura en función de las circunstancias y de las nuevas amenazas que pudiesen surgir66. De esta manera no incurriría jamás en contradicción y tendría siempre las manos libres para condenar y retirar de la circulación cualquier texto pernicioso. Las penas impuestas para quienes imprimiesen o vendiesen libros sin licencia alcanzaron una severidad desconocida -pérdida de bienes y destierro perpetuo, mientras que para aquellos que vendieran o imprimieran libros prohibidos estaba reservada la pena de muerte y la pérdida de todos sus bienes. Se comprende así, bajo este clima de represión, que los editores y libreros se cuidasen mucho de incurrir en estos delitos o en apostar por obras de dudosa ortodoxia (a pesar de las licencias) y que ejerciesen la autocensura, pues en

\footnotetext{
65 Sobre las disposiciones legales aprobadas en la pragmática de 1558 pueden consultarse los trabajos de Lucía Megías (1999) y Fernández Terricabras (2018). Acerca de la circulación de manuscritos, que con frecuencia podían escapar a la censura, véase Bouza (2001).

${ }^{66}$ Las funciones complementarias de la Inquisición, que censuraba ediciones ya impresas y en circulación, han quedado descritas en Pinto (1983: 87-95).
} 
cualquier momento un mal paso con el Santo Oficio podía conducir a la requisación de una edición completa y a la consecuente pérdida de la inversión. En este contexto, la Inquisición estableció que se visitasen periódicamente las librerías de Castilla para inspeccionar (mediante un gran despliegue escenográfico por el que tomaban literalmente una villa) los libros que allí se vendían. Igualmente, desde 1558 se obligó a los libreros a mostrar en sus establecimientos el listado de obras prohibidas con el fin de que el público tuviese entero conocimiento de las mismas. Por último, se hizo preciso articular un sistema de vigilancia que defendiese las fronteras del reino -particularmente en los puertos del norte- frente a la importación de libros heréticos procedentes del extranjero. De ahí que, por real cédula de 8 de octubre de 1558, se pusiese en manos de la Inquisición el control sobre esta clase de mercaduría. Así, desde entonces, junto a los oficiales reales encargados de cobrar impuestos en las aduanas, operaron los comisarios del Santo Oficio, que revisaban con celo las partidas de libros que entraban en España en permanente comunicación con la Suprema, desde donde recibían frecuentes avisos e instrucciones. La censura oficial, la autocensura y la constante vigilancia inquisitorial, por consiguiente, definieron el nuevo clima cultural al que hubo de someterse la literatura española $-y$, en general, toda la vida intelectual- desde los primeros años del reinado de Felipe ${ }^{667}$.

Para completar estos mecanismos de vigilancia era todavía necesario un paso más, que consistía en definir con absoluta claridad la frontera que separaba lo ortodoxo de lo heterodoxo. Y era necesario hacerlo a partir de una ideología bien definida donde los intereses de la Corona y los principios de la confesión católica constituyesen un cuerpo doctrinal tan coherente y articulado como el conjunto de instituciones encargado de ejercer el control sobre las ideas y creencias de los súbditos. En ese sentido, se advierte no solo un comportamiento negativo (o reactivo) frente a las amenazas que con el tiempo se fueron presentando -el iluminismo, el erasmismo o el luteranismo- sino la maduración

\footnotetext{
${ }^{67}$ Sobre las funciones de la censura inquisitorial en el aparato de control ideológico establecido por la Monarquía ha escrito Pinto (1980), quien estudió también de manera específica tanto la visita a las librerías (1983: 125-136), como las medidas adoptadas para fiscalizar la circulación de libros (1983: 97-124).
} 
de una ideología "oficial" de signo positivo (y carácter programático) que paulatinamente se trataría de imponer desde la cúspide del poder por medio del adoctrinamiento social y la represión de cualquier forma de disidencia. Evidentemente, la Inquisición desempeñó una función crucial en estos procesos, en los que se observa un progresivo avance de la perspectiva "española" a la hora de fijar la nueva ortodoxia, tal y como revelan los célebres catálogos de libros prohibidos. Así, si los índices españoles de 1540, 1547 y 1551 fueron en esencia una réplica de los publicados en años precedentes en Lovaina -la universidad más importante del Imperio- a los que solo se añadían algunos títulos al final del listado, nada parecido se observa ya en los de 1554 y $1559^{68}$. En efecto, a diferencia de los anteriores, estos dos catálogos fueron confeccionados sustancialmente en España y denotan la creciente importancia de los reinos peninsulares como nuevo centro de gravedad (en lo político y en lo ideológico) de la Monarquía Habsburgo.

El primero de ellos surgió como consecuencia de la entrada en España de numerosas ediciones de la Biblia y del Nuevo Testamento que carecían de licencia. Muchas contenían sumarios, índices, escolios, títulos y marginales que se apartaban peligrosamente de la ortodoxia, de ahí que la Inquisición diese orden de censurar y requisar aquellos libros. La colecta fue sorprendentemente abundante, de manera que el Santo Oficio decidió impulsar la preparación y publicación de la Censura Generalis o censura de Biblias de 1554, la primera de carácter expurgatorio en la tradición española. Allí fueron señaladas hasta cincuenta y siete ediciones de las Sagradas Escrituras (salidas de París, Lyon, Amberes, Basilea, Estrasburgo y Venecia) para su corrección y enmienda. La tarea se encomendó a los profesores de teología de Salamanca y Alcalá, que colaboraron estrechamente con la Inquisición para limpiar de impurezas (y permitir después la circulación) de aquellas Biblias (no vernáculas) impresas desde 1528, pues se perseguían ante todo los errores introducidos por las herejías más recientes. Sea como fuere, la implantación de tales restricciones no resultaría sencilla a la postre, ya que la resistencia del pueblo y de numerosos

\footnotetext{
${ }^{68}$ Una visión panorámica de los diversos índices inquisitoriales promulgados en la España del siglo XVI se halla en Martínez de Bujanda (2000).
} 
centros monásticos fue notable ${ }^{69}$. No obstante, el índice que verdaderamente marcó un hito en la historia cultural española fue el publicado en 1559, promovido por el inquisidor general Fernando de Valdés, con el que culminó una larga serie de medidas coercitivas adoptadas a lo largo de la década ${ }^{70}$. Por esta vía, a la inspección de librerías y a la vigilancia de fronteras -ya citadas- se sumó la supresión de todas las licencias especiales para la lectura de libros prohibidos, al tiempo que se condenaba su tenencia. Para que la medida fuese efectiva, la Inquisición -como refuerzo de la visita anual a librerías y bibliotecas encomendada a obispos y corregidores- revisó también numerosas bibliotecas privadas e institucionales, como las de monasterios, conventos y universidades, que fueron sometidas desde estas fechas a una rigurosa vigilancia. Por último, se estableció que solo la Inquisición tuviese autoridad para fijar la ortodoxia o heterodoxia de una obra con el fin de evitar opiniones dispares y desajustes que debilitasen los engranajes del sistema. Así que en este aspecto, como en el caso de las licencias de impresión, la centralización y la unificación de criterios determinaron la acción política de la Monarquía ${ }^{71}$.

Como colofón de todas estas medidas, en agosto de 1559 se publicó el famoso Catálogo de libros prohibidos de la Inquisición Española, solo posterior en algunos meses al Index romano promovido por Paulo IV. En este caso, el contexto internacional invitaba a marcar distancias con Roma, pues se trataba de definir desde las altas instancias de la Monarquía una ortodoxia netamente hispana que respondiese a los principios de un confesionalismo católico cortado a la medida de la Corona y ajustado a las particularidades de la cultura española, de su espiritualidad, de su literatura ${ }^{72}$. Al calor de la lucha faccional auspiciada

\footnotetext{
${ }^{69}$ Los trabajos inquisitoriales llevados a cabo en 1554 para la censura de Biblias han merecido el análisis de Tellechea Idígoras (1962a). Recientemente, Vega (2020) ha analizado pormenorizadamente el proceso de expurgación y la importancia histórica de este primer ensayo como anticipo del que se realizaría con carácter general en el índice de Quiroga (1984).

${ }^{70}$ Como explica González Novalín (1984), una vez nombrado inquisidor general en 1547, Valdés emprendió reformas internas en el Santo Oficio que pronto convertirían la institución en un órgano de represión implacable al servicio de la Monarquía.

${ }^{71}$ Sobre el control de la lectura, véase Pinto (1983: 137-146). Para conocer la evolución histórica de la censura ejercida en España por el Santo Oficio entre 1480 y 1559 es fundamental el trabajo de Martínez Millán (1980). Una visión sintética de aquellos procedimientos de control emprendidos por la Inquisición se halla también en Pinto (1984).

72 El carácter diferencial de los índices inquisitoriales españoles con respecto a los de Roma ha sido explicado por Martínez de Bujanda (2017).
} 
por su promotor, Fernando de Valdés, el Índice de 1559 se elaboró precipitadamente ante el inminente regreso de Felipe II a la Península. De hecho, para la confección de aquel copioso listado, la Suprema reprodujo lo recogido en otros índices extranjeros inmediatamente precedentes -tal y como revelan decenas de títulos completamente desconocidos en España- a los que sumó, en su afán compilatorio, el fruto de la intensa actividad censoria desarrollada por el Santo Oficio desde principios de la década. Esa tarea casi obsesiva de fiscalización de la cultura había sido ejercida por un gran número de calificadores, cuya labor ordinaria había permitido acumular una copiosa documentación que ahora servía para alimentar el índice ${ }^{73}$. Finalmente, se realizó un último esfuerzo para revisar a toda prisa un elenco de obras que, a juicio de los inquisidores, podían hallarse fuera de la ortodoxia, como ocurrió sin ir más lejos- con textos de Bartolomé Carranza, fray Luis de Granada o Francisco de Borja impresos en fecha reciente. Así pues, en 1559 el Consejo de Inquisición ordenó, centralizó y dio publicidad a todo aquel caudal de información acumulado durante años ${ }^{74}$. Se trataba, en fin, de frenar la difusión de cualquier texto que contuviese "errores y doctrinas escandalosas y sospechosas y malsonantes contra nuestra sancta fee catholica", tal y como rezaban los preliminares del catálogo ${ }^{75}$. Como era de esperar, Valdés y sus colaboradores, entre los que destacó el ínclito Melchor Cano, emplearon el Índice para situar en los márgenes de la heterodoxia todas aquellas tendencias espirituales contra las que llevaban años combatiendo en las más diversas instituciones eclesiásticas

\footnotetext{
${ }^{73}$ A la luz de algunas secuencias editoriales, resulta evidente la existencia de un procedimiento ordinario de censura que interrumpió bruscamente la edición de algunas obras desde la primera mitad de la década de 1550. Ese parece ser el caso del Lazarillo de Tormes, que tras el clamoroso éxito alcanzado en 1554 deja de imprimirse desde esa fecha para pasar después a engrosar el índice de 1559. Como sospecha Rico (2011: 101-102), esto pudo deberse a "un temprano entredicho de la censura", pues la prohibición de Valdés "no era cosa del momento: como tantas otras veces, debió hacerse ya en 1554 por el procedimiento ordinario de una «carta acordada» por una autoridad inquisitorial”. Como apunta González Ramírez (2016: 476, n. 4), este pudo ser también el caso de la traducción española de El asno de oro de Apuleyo o de ciertas comedias de Bartolomé Torres Naharro, Jaime de Huete o Francisco de las Cuevas, que se editaron por vez primera entre 1550 y 1552 y no volvieron a disfrutar de la difusión impresa antes de la publicación del índice valdesiano, donde después fueron incluidas.

${ }^{74}$ El procedimiento seguido en el seno de la Inquisición para la elaboración del catálogo ha quedado descrito en Martínez Millán (1979).

${ }^{75}$ Acerca de las categorías y conceptos que presidieron la labor censoria en el siglo XVI, véanse el análisis y las reflexiones de Vega (2012 y 2013).
} 
y académicas y que ahora, debido a las circunstancias excepcionales que concurrieron tras el descubrimiento de los focos luteranos, constituían un blanco a su alcance ${ }^{76}$. Así, las obras de los grandes heresiarcas y de todos los condenados por la Inquisición quedaron allí señaladas, al igual que los textos judíos y musulmanes de sesgo anticatólico o los libros de magia -como no podía ser de otra forma-, pero junto a aquellas composiciones (manifiestamente perniciosas para la república) figuraban también todas las traducciones de la Biblia a lengua vernácula, todas las obras de devoción en romance, los textos de controversia religiosa contra los protestantes, las cumbres del recogimiento y de la mística, el legado del humanismo cristiano y del erasmismo, las obras de entretenimiento que tratasen de forma irreverente los asuntos de la fe e incluso cualquier texto anónimo que circulase por el reino (y que por ello resultase sospechoso) ${ }^{77}$. De este modo, algunas de las corrientes religiosas y culturales más fecundas del período anterior quedaron condenadas y la rama más floreciente de la espiritualidad renacentista española cercenada de cuajo u obligada a seguir la guía de la nueva ortodoxia ${ }^{78}$.

Si tomamos como piedra de toque lo acontecido con algunos autores espirituales de la época -Francisco de Borja, fray Luis de Granada, Juan de Ávila

\footnotetext{
${ }^{76}$ Son bien conocidas, por ejemplo, las distintas corrientes espirituales surgidas en el seno de la Orden de Santo Domingo, cuyo enfrentamiento desencadenó cruentas disputas en ámbitos tan señalados como el Colegio de San Gregorio de Valladolid. En ese marco debe entenderse la ofensiva de Melchor Cano contra Bartolomé Carranza o fray Luis de Granada, cuya sensibilidad evangélica chocaba frontalmente contra el rígido escolasticismo del censor. Al respecto, véanse los trabajos clásicos de Beltrán de Heredia (1941) y Tellechea Idígoras (1962b).

77 Una clasificación de las tipologías textuales que padecieron la censura inquisitorial (mentalidad científica, cristianismo heterodoxo y obras satíricas y burlescas) se ofrece en Márquez (1980: 159-176). De manera más específica, pueden conocerse las corrientes espirituales condenadas en el índice de Valdés por medio de Asensio (1988); mientras Martínez de Bujanda (1980) demuestra el reducido impacto del catálogo sobre la literatura de ficción, que no se hallaba entre sus principales objetivos. Con todo, fueron recogidas en el índice español de 1559, por diversas razones, obras de Gil Vicente, Hernando de Talavera, Torres Naharro, Juan del Encina o Jorge de Montemayor, además del Lazarillo de Tormes o el Cancionero general.

${ }^{78}$ Fueron numerosos los autores espirituales que, tras el viraje ideológico de la Monarquía, se vieron obligados a adaptar el sentido de sus escritos a la nueva orientación confesional. Así ocurrió, como explica Martínez Millán (2013), con Juan de Ávila, cuya obra Audi, filia (1556), tras ser condenada en el índice de Valdés, no alcanzaría de nuevo la difusión impresa hasta 1574 en una edición póstuma al cuidado de sus discípulos. Entre sus páginas, el paulismo evangélico de primera hora se había transformado bajo el influjo del catolicismo tridentino para superar la censura y asumir el tren de los tiempos. En el mismo sentido ha de interpretarse lo vivido por fray Luis de Granada, quien hubo de rehacer el Libro de la oración y la meditación (1554) y la Guía de pecadores (1556) para que pudiesen imprimirse de nuevo, una vez retocados, en 1566 y 1567 respectivamente, ya con el beneplácito del Santo Oficio. De todo ello da cuenta Huerga (1993).
} 
o Jorge de Montemayor- tendremos una noción más clara de lo sucedido, pues todos ellos tuvieron problemas con el Santo Oficio y la mayoría hubieron de abandonar España por entonces ante el avance de la intransigencia. Entre aquellos, el caso más relevante fue sin duda el de Bartolomé Carranza, insigne teólogo dominico (presente en Trento), quien había embarcado hacia Inglaterra en 1554 junto al príncipe Felipe para auxiliarlo en cuestiones de Estado. Allí participó activamente en todas las iniciativas destinadas a devolver el reino a la obediencia de Roma y, como miembro del sínodo de Londres, recibió el encargo de escribir sus Comentarios sobre el catecismo cristiano (Amberes, 1558), que a la postre serían condenados por la Inquisición. Llamado por el Rey, pasó a Flandes en 1557, donde tuvo noticia -como resultado de sus pesquisas- tanto de la conversión al protestantismo de algunos españoles que frecuentaban las universidades del norte de Europa como de la exportación de libros heréticos a España desde los Países Bajos. Todo ello incrementó la sensación de alarma en la cúspide de la Monarquía y puso en guardia al Santo Oficio, que extremó la vigilancia de las fronteras peninsulares ${ }^{79}$. A la muerte de Martínez Silíceo, fue nombrado arzobispo de Toledo el 27 de febrero de 1558, lo que desencadenó los odios de sus enemigos, como fray Bernardo de Fresneda, confesor de Felipe II, quien selló entonces una alianza con Valdés para destruirlo ${ }^{80}$. Carranza regresó a España en el verano de 1558 con intención de ocupar la sede primada, a la que llegó entrado el mes de octubre tras visitar la Corte de Valladolid y confortar en Yuste al Emperador en sus últimos momentos. Desde entonces, inició una intensa labor pastoral inspirada en el mejor reformismo católico, mientras a sus espaldas Fernando de Valdés, en connivencia con Fresneda y Cano, ultimaba una conspiración contra el arzobispo de Toledo tras obtener poderes especiales del $\mathrm{Papa}^{81}$. Finalmente, con el consentimiento explícito de

\footnotetext{
${ }^{79}$ Sobre el clima religioso reinante en Flandes entre 1557 y 1558 y la labor ejercida por Carranza, véase Tellechea Idígoras (1965).

${ }^{80}$ La trama urdida contra Carranza por Valdés, Cano y Fresneda ha sido reconstruida por Pizarro (1994).

${ }^{81}$ En enero de 1559 Valdés había obtenido poderes especiales de Paulo IV para controlar el comercio editorial, investigar por medio de los confesores la tenencia de libros prohibidos y transferir al brazo secular para su ejecución a todo propagador de la herejía a pesar de su abjuración. Finalmente, obtuvo potestad por espacio de dos años para detener y procesar en España a cualquier autoridad eclesiástica (incluso obispos y arzobispos), facultad que le permitiría detener a Carranza pocos meses después. Estos hechos fueron descritos por
} 
Felipe II, Carranza sería detenido por la Inquisición el 22 de agosto de 1559 cuando visitaba su archidiócesis. En su contra se esgrimieron algunos testimonios de los luteranos apresados en Valladolid, como los de Carlos de Seso o fray Domingo de Rojas ${ }^{82}$, así como la implacable censura de Melchor Cano a sus Comentarios, donde detectó (con su olfato de can) unas formas de devoción muy próximas al iluminismo de antaño -la lectura de la Biblia en lengua vulgar, la alusión frecuente al Espíritu Santo o la formación de conventículos en torno a un guía espiritual- junto a otras proposiciones muy cercanas a la justificación por la fe. Con estos argumentos, y a pesar de la temprana recusación de Valdés, se iniciaría entonces un interminable proceso inquisitorial que solo se cerraría en Roma a la altura de $1576^{83}$. Con la defenestración política de Carranza desaparecía toda una vía del reformismo católico en España, que quedaría definitivamente desacreditada tras los acontecimientos de 1558$1559^{84}$.

Por esos mismos años fallecieron el doctor Egidio (1555), Juan de Vergara (1557), el Arcediano del Alcor (1559), el doctor Laguna (1559) y el doctor Constantino (1560), esto es, algunas de las personalidades más eminentes salidas de Alcalá que durante el reinado de Carlos V habían sido emblema de un catolicismo renovador de inspiración evangélica opuesto (e incompatible a la larga) con ese otro catolicismo intelectualista, dogmático y formalista que defendían con ardiente celo Fernando de Valdés y Melchor Cano. La lucha que estos libraron en la Corte representó, pues, la escena final de una tragedia en la que, sin embargo, habían participado desde hacía cuarenta años numerosos actores, desde Martín Lutero a Paulo IV, pasando por los príncipes alemanes, el

González Novalín (1968: I, 305-310) e integrados en el seno de su argumentación por Fernández Terricabras (2018).

82 Desde la primavera de 1558 al verano de 1559 diversos encausados en el proceso inquisitorial seguido contra los luteranos de Valladolid sugirieron ciertos vínculos entre sus creencias y la predicación y magisterio de Bartolomé Carranza. En particular, su discípulo y compañero de hábito fray Domingo de Rojas, viéndose perdido, terminó censurando los escritos del arzobispo en un desesperado intento de ser reconciliado. No lo consiguió, pero dio argumentos a los inquisidores para armar la acusación contra Carranza. De todo ello da cuenta Tellechea Idígoras (1958).

83 La figura de Bartolomé Carranza (junto a la de otros destacados contemporáneos) recibió cumplido tratamiento en la obra magna de Tellechea Idígoras (2003-2007), donde se ofrece una riquísima información de índole espiritual, social y cultural sobre los protagonistas de aquella encrucijada. Una narración sintética de lo sucedido se ofrece en Tellechea Idígoras (1984).

${ }^{84} \mathrm{Al}$ respecto, véanse las recientes reflexiones de Giordano (2018). 
Emperador o el rey de Inglaterra. Retirado Carlos V de la política internacional y perdida la esperanza de una reconciliación entre católicos y protestantes tras la paz de Augsburgo (1555), Europa inició un rápido proceso de polarización confesional donde ya no hubo espacio ni para el irenismo ni para cualquier otra especie de vía media (desde el erasmismo al recogimiento) vinculada al humanismo cristiano o a ciertas formas de devoción inspirada. Por si fuera poco, la intransigencia protestante en el Imperio (que había impedido cualquier compromiso dogmático a pesar de los esfuerzos de Carlos V) se unió desde 1555 a la intransigencia de Paulo IV, de manera que con su pontificado se impuso en Italia la férrea represión de toda espiritualidad ajena a la más estricta ortodoxia. En el caso de Roma, la persecución de los spirituali y de los cardenales Pole y Morone, así como la publicación de su propio Index librorum prohibitorum en 1559, definieron con absoluta claridad la posición del papa Caraffa ${ }^{85}$. España, evidentemente, no podía actuar a espaldas de la realidad europea, de manera que cuando la heterodoxia peninsular entroncó con el mundo de la Reforma (en pleno proceso de maduración institucional) y florecieron los conventículos donde se leían obras impresas en Ginebra (Sevilla) o se exponían ideas y doctrinas aprendidas en el extranjero (Valladolid), la Monarquía hubo de rendirse a la evidencia y aceptar los postulados de Valdés.

La tolerancia y la benevolencia, al fin y al cabo, no habían logrado atajar el problema religioso en los territorios peninsulares. Antes al contrario, si antaño los conventículos de alumbrados fueron los que encarnaron la herejía iluminista con sus desviaciones (el dejamiento), ahora este espíritu de disidencia había adquirido una nueva dimensión -mucho más preocupante- con aquellos grupos de luteranos que esgrimían ya en su predicación doctrinas como la justificación por la fe, plenamente arraigadas en la teología protestante ${ }^{86}$. Para los inquisidores se trataba, en suma, de evitar a toda costa que se constituyese en España una Iglesia evangélica -a semejanza de lo que ocurría por entonces en

\footnotetext{
${ }^{85}$ Acerca de la política de represión emprendida por Paulo IV, véase, en el marco de la historia de la Iglesia, Jedin (1978: 666-670).

${ }^{86}$ Como explica Tellechea Idígoras (1982), frente al desconocimiento generalizado de la teología protestante que manifestaron habitualmente los españoles acusados de luteranismo, en los focos de Sevilla y Valladolid se aprecia ya una formación intelectual y una dinámica social que, con probabilidad, habría dado lugar a la fundación de una Iglesia evangélica en España.
} 
Francia- que ofreciese a los súbditos un horizonte de liberación y una bandera para quebrantar la autoridad real. En consecuencia, si se deseaba conservar la paz y la estabilidad interna de los reinos hispánicos, así como la unidad de su Iglesia, era preciso -como advertía Carlos V desde Yuste- eliminar de raíz la herejía antes de que su ponzoña se extendiese por España. De ahí la estrecha colaboración mantenida entre la Corona y el Santo Oficio en esta causa, cuya gravedad no permitió la reconciliación de muchos procesados, quienes fueron ejecutados bajo la acusación de rebeldía. A la luz de la experiencia no había ya duda: la herejía protestante no representaba solo un atentado contra la fe católica, sino que constituía al mismo tiempo un delito de lesa majestad que ponía en riesgo el edificio político de la Monarquía. Solo en ese contexto puede entenderse la virulenta reacción de Valdés, los poderes especiales otorgados por Paulo IV y el consentimiento expreso de la Corona a todas sus acciones, pues la debacle vivida en Alemania justificaba el rigor de unas medidas tan excepcionales ${ }^{87}$. Con aquella severa medicina, en fin, la Monarquía impidió que el protestantismo penetrase en España, se conservó la paz en sus reinos y se preservó la unidad de la Iglesia, pero la nueva política se llevó consigo, como consecuencia de la intransigencia, los mejores frutos del humanismo cristiano, del espíritu de Alcalá, de una fe vivencial de inspiración evangélica que, desde tiempos de Isabel la Católica, había cobrado forma en multitud de corrientes y experiencias particulares ${ }^{88}$. En aquella hora suprema, sin embargo, todas estas tendencias (ortodoxas y heterodoxas) por las que discurría libremente la savia del Cristianismo quedaron condenadas, mientras aquella otra religión, formalista y ritualizada, intelectualista y racional, hija de la escolástica, triunfaba en aras de un catolicismo militante que, erigido en espiritualidad "oficial" de la Monarquía, garantizaría en adelante el control social y facilitaría los pertrechos de guerra para el enfrentamiento cultural contra el protestantismo que ya se avecinaba en la Europa confesional.

\footnotetext{
${ }^{87}$ Para comprender las implicaciones políticas, sociales e intelectuales de la herejía a mediados del siglo XVI, véanse las reflexiones de Pinto (1986).

${ }^{88}$ Véanse al respecto las observaciones de Bataillon (1966: 699-715), en las que el hispanista francés analiza las circunstancias que concurrieron en aquella encrucijada y reflexiona sobre las consecuencias espirituales y culturales del viraje político e ideológico experimentado por la Monarquía Hispana entre 1558 y 1559.
} 


\section{Un cambio de época: la España del confesionalismo}

A lo largo y ancho de la Monarquía, este doble movimiento de repliegue cultural y adoctrinamiento religioso representó la tónica dominante del período. Prueba de ello es la célebre pragmática de 22 de noviembre de 1559, por la que se prohibía a los súbditos de la Corona de Castilla marchar a estudiar al extranjero. En el mismo sentido, antes de abandonar los Países Bajos, Felipe II había ordenado que todos los estudiantes españoles en Lovaina (puestos bajo sospecha) regresasen a la Península y diesen cuenta de ello al Santo Oficio. Aquel otoño, pues, el mandato se extendió al resto de universidades europeas, con la excepción de Bolonia, Roma, Nápoles y Coímbra. Por entonces se reorganizó también la Iglesia católica en Flandes (dividida ahora en catorce obispados) y se nombraron nuevos inquisidores con el fin de convertir las instituciones eclesiásticas en un poderoso instrumento para la evangelización del pueblo llano y la represión de la herejía. Se trataba, en suma, de combatir con eficacia el proselitismo protestante y de homogeneizar por todos los medios el sistema de ideas y creencias de los súbditos con intención de garantizar la estabilidad de los reinos. He ahí la cuestión de fondo que inspiraría -en líneas generales- la política religiosa, social y cultural de Felipe II, quien, tras haber sido educado en la tolerancia por preceptores humanistas, se convirtió con el tiempo, paradójicamente, en el campeón de la ortodoxia como consecuencia del crudo realismo político que hubo de aplicar en el gobierno de la Monarquía. Algo semejante ocurrió con respecto al grupo de servidores que lo había acompañado desde su juventud -el partido del príncipe, los ebolistas-quienes, tras unos años de preeminencia en la Corte, fueron desplazados a mediados de la década de 1560 por una nueva estirpe de cortesanos cohesionada en torno al cardenal Espinosa, cuya cualificación personal (eran esencialmente letrados) e ideología (castellanista y confesional) resultaban mucho más apropiadas que las de los anteriores para comandar su imperio en semejante coyuntura. En lugar de una política de acuerdos con las elites locales para articular la gestión del territorio como ensayaron los ebolistas en Italia y Flandes- se prefería ahora, con Espinosa, una fuerte centralización institucional de la Monarquía en torno a 
Castilla y a los castellanos ${ }^{89}$. Fruto de esa deriva, la injerencia hispánica en la gobernación de otros reinos iría en aumento y no tardaría en desencadenar fuertes resistencias que a la postre pusieron en riesgo la autoridad real. Así ocurrió en Flandes tras la llegada del duque de Alba en 1566, cuyos métodos expeditivos levantaron a los Países Bajos e inauguraron un período de conflictos armados que se prolongaría por espacio de ochenta años. En el mismo sentido, el final de la transigencia religiosa en el interior de la Península lbérica alentó la adopción de nuevas y más rigurosas medidas destinadas a la asimilación de los moriscos, que constituían un peligro latente ante la amenaza del Turco. Así, desde la Chancillería de Granada se promulgó -bajo el auspicio de Pedro de Deza- la pragmática de 1567, que atentaba contra la forma de vida y las costumbres más arraigadas de una comunidad que, tras la caída del reino nazarí en 1492, había conservado casi inalterables sus señas de identidad. Ahora, sin embargo, las concordias de Carlos $\mathrm{V}$ quedaban atrás ante el avance del confesionalismo filipino, que rompía definitivamente aquel statu quo con su acelerada búsqueda de la homogeneidad cultural y religiosa. Aquella política, en fin, pronto desencadenaría la rebelión de las Alpujarras (1568) y daría paso a una desastrosa guerra civil que asolaría el sureste de Andalucía durante dos años $(1569-1571)^{90}$.

Estas fueron las consecuencias inmediatas del viraje experimentado por el Imperio de Felipe II tras su regreso a la Península en 1559. Fue entonces cuando, de manera directa, pudo comprobar el agotamiento de los reinos hispánicos y la necesidad de reestructurar las instituciones de la Monarquía para mejorar su operatividad y coordinar de manera centralizada el gobierno de sus distintos reinos. Con las reformas impulsadas en esta línea, en definitiva, perseguía la superación de las barreras jurisdiccionales impuestas por cada territorio para configurar un mando unitario que velase eficazmente por el interés general del cuerpo político. El centro de gravedad de este nuevo equilibrio sería España, tal y como evidenció el asentamiento de la Corte en Madrid (1561) y el

\footnotetext{
${ }^{89}$ La labor política ejercida por el cardenal Espinosa al frente de la Monarquía Hispana puede conocerse a través de Martínez Millán (1994b).

90 La vida y tragedia de los moriscos españoles entre 1492 y 1609 puede conocerse por medio del estudio general de Domínguez Ortiz y Vincent (1978).
} 
predominio del punto de vista hispánico en la administración de todos sus Estados. El Imperio Habsburgo de Carlos V, pues, se transformó por esta vía en la Monarquía Hispana de Felipe II, quien gobernaría desde El Escorial sus amplísimos dominios, desde Cuzco a Bruselas, a través de un sistema polisinodal cada vez más complejo y mejor articulado. De ahí que los letrados de Espinosa resultasen tan adecuados para despachar con diligencia el creciente tráfago de papeles que generaba el funcionamiento ordinario de la Monarquía, y que, a la muerte del cardenal (1572), se deslindasen cada vez con mayor precisión las tareas rutinarias (administrativas y jurídicas) de las verdaderas labores de gobierno, reservadas a los consejos y a un reducido grupo de cortesanos. Así pues, una vez pacificado Flandes y asentada su hegemonía en Italia, Felipe II pudo contemplar la política internacional desde la óptica española, lo que implicaba atender prioritariamente a la defensa de la Península ante el avance del Islam. Pasados unos años, estos esfuerzos alentarían la constitución de la Liga Santa (junto a la República de Venecia y los Estados Pontificios), que vino motivada por la deposición del emir de Túnez (aliado de España) y el desembarco otomano en Chipre (territorio veneciano). La gran armada reunida entonces en Creta derrotaría finalmente a la flota otomana en el golfo de Lepanto (Grecia) el 7 de octubre de 1571 en una colosal batalla naval que daría paso a un nuevo orden en el Mediterráneo ${ }^{91}$. Cerrado aquel frente, la atención de la Monarquía podía centrarse ya en el norte de Europa, donde los problemas en los Países Bajos pronto se multiplicarían tras la desastrosa campaña militar contra los rebeldes holandeses encabezada por el duque de Alba y don Fadrique de Toledo (1572-1573) ${ }^{92}$. Por si fuera poco, aquellos insurrectos del Continente serían apoyados desde estas fechas por Isabel I de Inglaterra (excomulgada en 1570), cuyos corsarios (John Hawkins y Francis Drake) hostigaban la navegación española en el Caribe desde finales de la década anterior. Con el tiempo, la tensión entre ambas potencias iría en aumento y desembocaría en el intento de invasión protagonizado por la gran armada (1588), empresa donde se

91 Todas las circunstancias que concurrieron en el Mediterráneo a comienzos del reinado de Felipe II pueden ser conocidas a través de la obra clásica de Braudel (1976). Para la batalla de Lepanto, remito al trabajo monográfico de Rivero Rodríguez (2008).

${ }_{92}$ Los diversos episodios que jalonaron la estancia del duque de Alba en los Países Bajos han sido narrados, muy por extenso, en Maltby (1985: 171-318). 
entreveraban motivaciones políticas y religiosas, como era habitual en la Europa del confesionalismo ${ }^{93}$.

La defensa de la ortodoxia católica se convirtió, en efecto, en el principio ideológico fundamental sobre el que gravitó la política de la Monarquía Hispana tanto en el interior de sus fronteras (persiguiendo la herejía y promoviendo los acuerdos adoptados en Trento) como en el exterior (combatiendo tanto a los infieles como a los protestantes). Para ello, una vez descartadas aquellas corrientes espirituales que, por unas razones o por otras, entrañaban algún riesgo para la unidad de la Iglesia o la autoridad real-desde el antiintelectualismo del recogimiento al biblismo del humanismo cristiano- era preciso definir los fundamentos del catolicismo hispano que la Monarquía asumiría como propio. Este habría de marcar diferencias con respecto al protestantismo y servir, al mismo tiempo, como instrumento para abordar los problemas del presente y ejercer un control efectivo sobre la sociedad. La Corona encontró respuesta a estas demandas en el tomismo, que como reacción a aquellas vías de espiritualidad más renovadoras se había desarrollado en tiempos de Carlos V en determinados ámbitos académicos, como el Colegio de Santo Tomás de Sevilla, fundado en 1517 bajo el patrocinio del dominico Diego de Deza, o la Universidad de Salamanca, donde floreció la segunda escolástica tras el decisivo magisterio de Francisco de Vitoria ${ }^{94}$. Este influyó de un modo $u$ otro sobre teólogos y juristas de la talla de Melchor Cano, Domingo Báñez, Domingo de Soto o Francisco Suárez, quienes conformaron el núcleo de la Escuela de Salamanca durante la segunda mitad del siglo $\mathrm{XVI}^{95}$. Con sus escritos, el catolicismo encontró un valioso soporte para acometer desde una perspectiva moral y religiosa asuntos de plena actualidad relativos al derecho natural (la libertad e igualdad entre los hombres), el derecho de gentes (polémica de los justos títulos en América), el derecho internacional (la soberanía, el derecho de resistencia, la guerra justa) o a la economía (la legitimidad del

\footnotetext{
${ }^{93}$ Las difíciles relaciones entre Felipe II y la Inglaterra de Isabel I han sido estudiadas por Rodríguez Salgado (2000).

${ }^{94}$ Sobre el desarrollo del tomismo en tiempos de Carlos $\mathrm{V}$ y su oposición a otras corrientes espirituales como el erasmismo o el recogimiento, véase Martínez Millán (2001: 142-143).

95 Una visión plural y actualizada de la Escuela de Salamanca se ofrece en los trabajos reunidos por Poncela (2015) y Langella y Ramis (2021).
} 
comercio y del enriquecimiento personal), pues la segunda escolástica adoptó una orientación eminentemente práctica frente al enfoque especulativo de la teología medieval. Fe y razón quedaban de nuevo hermanadas por este camino, pues al tronco de la escolástica (basada en la Sagrada Escritura y la tradición de la Iglesia) se sumaba ahora el rigor metodológico y la mirada crítica sobre la realidad (presente y tangible) propios del humanismo. Una vez definida la nueva ortodoxia gracias a la segunda escolástica y asumidos en su integridad los acuerdos de Trento (1563) ${ }^{96}$, era preciso asegurar su aplicación a la enseñanza superior, lo que propició la visita a las universidades de Alcalá de Henares (1564) y Salamanca (1567), con el fin de implantar en ellas el espíritu tridentino y enderezar el rumbo de sus estudios ${ }^{97}$. En la misma línea, la Corona trató de establecer estos principios en la sociedad por medio de la predicación y la catequesis. De ahí que se promoviese la labor pastoral de obispos y sacerdotes, que se difundiesen numerosos catecismos y que se cuidase con mayor esmero la formación moral e intelectual del clero, pieza esencial para el adoctrinamiento del vulgo. Los jesuitas desempeñaron un papel muy relevante en esta tarea, pues, tras reorientar su carisma para adaptarlo al curso de los tiempos, pusieron toda su experiencia pedagógica y oratoria al servicio de Roma y del confesionalismo católico (he aquí el origen de la ratio studiorum), que empleó

\footnotetext{
${ }^{96}$ Como explica Fernández Terricabras (2016), frente a la posición más dialogante de quienes no habían perdido la esperanza de alcanzar un acuerdo de compromiso con los protestantes (como Catalina de Médici o el emperador Fernando I), Felipe II impulsó la reunión y clausura del concilio de Trento, que finalmente celebró su tercer y último período de sesiones entre 1562 y 1563. En él quedó definitivamente definida la ortodoxia católica y cerrada, por consiguiente, cualquier posibilidad de encuentro con el mundo de la Reforma. Pocos meses después, en julio de 1564, el Rey Prudente convertiría aquellas disposiciones en ley para sus reinos por medio de una pragmática. Desde entonces, el dogma católico alcanzaría dimensión legislativa en la Monarquía Hispana y cualquier tipo de disidencia religiosa sería juzgada como delito.

${ }^{97}$ El control sobre las universidades se había iniciado ya a finales de la década de 1550, como se observa con las frecuentes visitas a la Universidad de Salamanca llevadas a cabo por Melchor Cano (1557), Hernando Pérez (1557-1558), Montalvo (1559) o Diego de Covarrubias (1560), que culminarían con la aprobación en 1561 de unos nuevos estatutos. En ellos se establecen rigurosamente los mecanismos de provisión de plazas, los métodos de enseñanza autorizados y el contenido de las materias impartidas en cada cátedra. A mediados de la década de 1560 se aprueban también sus estatutos de limpieza de sangre, de manera que la Universidad de Salamanca padece el clima de vigilancia intelectual y bloqueo social que será propio del período confesional. La universidad de corte renacentista, en suma, se diluye como consecuencia del intervencionismo regio, tal y como explica Rodríguez San Pedro (2002).
} 
desde aquella hora todos los medios a su alcance para extender los principios de la nueva ortodoxia por el cuerpo social de la Monarquía ${ }^{98}$.

La cultura española, finalmente, sufrió también una importante metamorfosis como consecuencia de este "cambio de atmósfera". En cuanto a las formas de ficción en prosa, decaen algunos géneros, como los libros de caballerías, que dejan atrás su período de máximo esplendor creativo y editorial; y casi desaparecen otros, como el diálogo, molde propicio para una controversia ideológica que ya no era posible en la España del Rey Prudente. Simultáneamente, emergen nuevas vetas narrativas, como los libros de pastores, donde el refinamiento cortesano se desplaza a la Arcadia para cantar al amor en un espacio de libertad y pureza; o como el romance griego, que por medio de la hibridación genérica renueva la literatura de entretenimiento al abrigo de la tradición clásica. El Lazarillo de Tormes y El Abencerraje, por su parte, aunque inciden en cuestiones candentes -la degradación moral de la sociedad cortesana, el primero; el problema de la libertad y la tolerancia, el segundohabrán de esperar al final de la centuria para ver florecer a su progenie. La traducción y edición de textos griegos, en fin, fue mirada con creciente sospecha99, al igual que los trabajos filológicos emprendidos por el humanismo cristiano, que desde mediados del XVI constituyeron una empresa arriesgada, tal y como demuestran los casos de fray Luis de León o de Benito Arias Montano, cuya Biblia Políglota de Amberes o Biblia Regia (1572), preparada por encargo de Felipe II, sería denunciada por León de Castro ante el Santo Oficio. La literatura espiritual, en la misma línea, hubo de sufrir una constante vigilancia destinada a evitar que los ardores místicos derivasen en iluminismo o que se filtrasen proposiciones filoprotestantes en obras de fervorosa piedad evangélica.

El mundo de la imprenta -severamente castigado por el proceso confesional- padeció también los rigores de los nuevos procedimientos

\footnotetext{
98 Los fundamentos de la política confesional de la Monarquía, basada en la asunción de la segunda escolástica, la reforma de las órdenes religiosas, la catequización del pueblo, la vigilancia inquisitorial, el control de la enseñanza y de la cultura y la adopción de los acuerdos de Trento pueden conocerse por medio de Martínez Millán y De Carlos (1998: 101-130) y Martínez Millán (2001: 147-159).

99 Como explica Mangue (2010: 113-120), en el Concilio de Trento se prohibió la lectura generalizada de la Biblia en hebreo y griego, de manera que, a ojos de la Iglesia de Roma, cualquier texto compuesto en esta última lengua tenía en sí mismo sabor a herejía.
} 
burocráticos, pues estos alteraron la morfología del libro impreso, ralentizaron su producción y obligaron a cuidar hasta el extremo su contenido para evitar toda sombra de heterodoxia. El mercado interior, al mismo tiempo, quedó limitado ante la prohibición de estampar obras anónimas y el inevitable retroceso de la literatura devota en lengua vulgar. En un sector ya debilitado por la escasez de capitales y la carencia de una adecuada red de distribución, en fin, estos obstáculos adicionales propiciaron el desarrollo de numerosas estrategias comerciales encaminadas a acertar con el gusto del público y a rentabilizar con ello la inversión. El mundo del libro y, en consecuencia, la misma literatura de ficción hubieron de buscar caminos alternativos (como la hibridación o el desarrollo de nuevas fórmulas editoriales) ${ }^{100}$ para salir adelante en un período lleno de incertidumbres. La Inquisición, por último, prosiguió con su labor censoria, si bien pudo acometerla ya con cierto sosiego tras la precipitada confección del Índice de Valdés (1559). El resultado de estos trabajos, iniciados en 1569 a instancias de Diego de Espinosa, fue el Catálogo de libros prohibidos (1584) promovido por el inquisidor general Gaspar de Quiroga ${ }^{101}$, donde se aprecia una mayor clemencia en los escrutinios. Como novedad, se levanta la prohibición que recaía sobre algunas obras, como el Lazarillo (castigado ya en 1573) ${ }^{102}$, que por su reconocida valía se autorizan ahora tras quedar expurgadas de toda impureza. Síntomas todos ellos, en fin, de un cambio de época en que la Monarquía Hispana de Felipe II, una vez superada la década de 1550, tomó la senda del catolicismo militante en una Europa fracturada religiosa y culturalmente que se encaminaba ya hacia un tiempo nuevo, la época del confesionalismo.

\footnotetext{
100 Baste con recordar los casos de La Diana de Montemayor, en cuya secuencia editorial se observan diversos procedimientos destinados a incrementar las posibilidades comerciales del volumen (desde la adición del Abencerraje pastoril al final de libro IV a la incorporación de un pequeño cancionero a modo de apéndice); o del mismo Abencerraje, cuyas tres versiones no pueden ser entendidas sin el contexto editorial que las acoge: primero surge bajo la apariencia de un pequeño libro de caballerías que se ofrece de manera independiente (la versión Crónica, 1561) y después -y siempre en este orden - la versión Diana (Valladolid, 1562), que refuerza los atractivos de la obra bucólica en forma de narración intercalada; y la versión Inventario (Medina del Campo, 1565), donde el relato de frontera cierra el cancionero personal de Antonio de Villegas y lo enriquece por medio de la diversidad. Al respecto, véase Torres Corominas (2013).

101 La trayectoria cortesana y espiritualidad de Gaspar de Quiroga han recibido tratamiento particular en Pizarro (2004).

${ }^{102}$ Acerca del Lazarillo castigado y su historia editorial, véase el trabajo de Coll-Tellechea (2010).
} 


\section{BiBLIOGRAFÍA}

AlONSO BURGOS, Jesús (1983). El luteranismo en Castilla durante el siglo XVI: autos de fe de Valladolid de 21 de mayo y de 8 de octubre de 1559. San Lorenzo de El Escorial: Swan.

ANDRÉS MARTín, Melquíades (2000). "La espiritualidad española en tiempo de Carlos V". En José Martínez Millán (coord.), Carlos V y la quiebra del humanismo político en Europa (1530-1558). Madrid: Sociedad Estatal para la Conmemoración de los Centenarios de Felipe II y Carlos V, vol. IV, pp. 169-177.

ANDRÉs MARTín, Melquíades (1986). "Corrientes culturales en tiempo de los Reyes Católicos y recepción de Erasmo". En Manuel Revuelta Sañudo y Ciriaco Morón Arroyo (eds.), El erasmismo en España. Santander: Sociedad Menéndez Pelayo, pp. 73-96.

ANDRÉs MARTín, Melquíades (1975). Los recogidos: nueva visión de la mística española (1500-1700). Madrid: Fundación Universitaria Española.

ANDRÉs MARTín, Melquíades (1973). Nueva visión de los "Alumbrados" de 1525. Madrid: Fundación Universitaria Española.

ASENSIO, Eugenio (1988). "Censura inquisitorial de libros en los siglos XVI y XVII. Fluctuaciones. Decadencia”. En Pedro M. Cátedra y María Luisa LópezVidriero (eds.), El libro antiguo español, I. Actas del primer Coloquio Internacional. Salamanca: Universidad de Salamanca, pp.21-37.

ASENSIO, Eugenio (1952). "El erasmismo y las corrientes espirituales afines", Revista de Filología Española (1952), XXXVI, pp. 31-99.

AVILÉS FERNÁNDEZ, Miguel (1984). "El Santo Oficio de la primera etapa carolina: alumbrados de Toledo de 1525 e Inquisición, procesos y procesados". En Joaquín Pérez Villanueva y Bartolomé Escandell Bonet (dirs), Historia de la Inquisición en España y América. Madrid: Biblioteca de Autores Cristianos, vol. I, pp. 443-473.

BATAILlon, Marcel (1966). Erasmo y España. Trad. Antonio Alatorre. MéxicoMadrid: Fondo de Cultura Económica (Segunda edición en español corregida y aumentada).

BATAILlON, Marcel (1952). “Jeanne D’Autriche, Princess de Portugal”. En Études sur le Portugal au temps de l'Humanisme. Coimbra: Universidade, pp. 257-283.

BELTRÁN DE HEREDIA, Vicente (1941). Las corrientes de espiritualidad entre los dominicas de Castilla durante la primera mitad del siglo XVI. Salamanca: Biblioteca de Teólogos Españoles.

Bergua CAVERo, Jorge (2006). Francisco de Enzinas: un humanista reformado en la Europa de Carlos V. Madrid: Trotta.

BOEGLIN, Michel (2016). "Corrientes heterodoxas y la recepción de la Reforma en Castilla bajo el reinado del emperador". En José Luis Betrán Moya, Bernat Hernández y Doris Moreno (eds.), Identidades y fronteras culturales en el mundo ibérico de la Edad Moderna. Barcelona: Bellaterra, Universidad de Barcelona, pp. 131-144.

BOEGLIN, Michel (2005). "Evangelismo y sensibilidad religiosa en la Sevilla del Quinientos: consideraciones acerca de la represión de los luteranos sevillanos". Studia historica. Historia Moderna (2005), XXVII, pp. 163-189. 
Bouza ÁlvaREZ, Fernando J. (2001). Corre manuscrito: una historia cultural del Siglo de Oro. Madrid: Marcial Pons.

BRAUDEL, Fernand (1976). El Mediterráneo y el mundo mediterráneo en la época de Felipe II. Madrid-México: Fondo de Cultura Económica.

BUNES IBARRA, Miguel Ángel de (2016). "Bastiones y presidios en el Mediterráneo occidental”. Sociedad Geográfica Española (2016), LIII, pp. 46-57.

BUNES IBARRA, Miguel Ángel de (2011). "Bases y logística del corso berberisco". En La expulsión de los moriscos y la actividad de los corsarios norteafricanos: XLI Jornadas de Historia Marítima, ciclo de conferenciasoctubre 2010, cuadernos monográficos, LXI, pp. 83-102.

BunEs IBARRA, Miguel Ángel de (2004). Los Barbarroja. Corsarios del Mediterráneo. Madrid: Aldebarán.

BUNES IBARRA, Miguel Ángel de (2000). "Carlos V y el imperio otomano". Torre de los Lujanes: Boletín de la Real Sociedad Económica Matritense de Amigos del País (2000), XLI, pp. 63-76.

CAmERON, Euan (2012). The European Reformation. Oxford: Oxford University Press.

CARGILL THOMPSON, William David James (1984). The political thought of Martin Luther. Brighton: Harvester Press; Totowa: Barnes \& Noble Books.

CARRASCO URGOITI, María Soledad (1972). "Las cortes señoriales del Aragón mudéjar y El Abencerraje". En Homenaje al profesor Casalduero. Madrid: Gredos, pp. 115-128.

CILVETI LECUMBERRI, Ángel (1986). "Lorenzo Valla y el nuevo paradigma intelectual". En Manuel Revuelta Sañudo y Ciriaco Morón Arroyo (eds.), El erasmismo en España. Santander: Sociedad Menéndez Pelayo, pp. 5372.

ColÁS LATORRE, Gregorio y SALAS AusÉNS, José Antonio (1982). Aragón en el siglo XVI: alteraciones sociales y conflictos políticos. Zaragoza: Universidad de Zaragoza.

Coll-TELLECHEA, Reyes (2010). Lazarillo castigado: historia de un olvido. Muerte y resurrección de Lázaro (1559-1573-1884). Madrid: Ediciones del Orto.

DE CARLOS MORALES, Carlos Javier (2000). "El régimen polisinodial bajo la égida de Cobos y Tavera". En José Martínez Millán (dir.), La Corte de Carlos V. Madrid: Sociedad Estatal para la Conmemoración de los Centenarios de Felipe II y Carlos V, vol I, tomo II, pp. 43-49.

De CaRlos Morales, Carlos Javier (1994). "El poder de los secretarios reales: Francisco de Eraso". En José Martínez Millán (ed.), La corte de Felipe II. Madrid: Alianza Editorial, pp. 107-148.

DomíngueZ OrTiz, Antonio y VinCENT, Bernard (1978). Historia de los moriscos. Vida y tragedia de una minoría. Madrid: Revista de Occidente.

DoussinAGUE, José María (1949). La política exterior de España en el siglo XVI. Madrid: Ministerio de Asuntos Exteriores.

EZQUERRA REVILLA, Ignacio (2000). “"La Casa de las infantas doña María y doña Juana". En José Martínez Millán (dir.), La Corte de Carlos V. Madrid: Sociedad Estatal para la Conmemoración de los Centenarios de Felipe II y Carlos V, vol. I, tomo II, pp. 125-152.

FERNÁNDEZ CONTI, Santiago (2000a). "La organización de la Casa del príncipe Felipe (1535-1546)". En José Martínez Millán (dir.), La Corte de Carlos V. 
Madrid: Sociedad Estatal para la Conmemoración de los Centenarios de Felipe II y Carlos V, vol. I, tomo II, pp. 97-121.

FERNÁNDEZ CONTI, Santiago (2000b). "La introducción de la etiqueta borgoñona y el viaje de 1548-1551”. En José Martínez Millán (dir.), La Corte de Carlos V. Madrid: Sociedad Estatal para la Conmemoración de los Centenarios de Felipe II y Carlos V, vol. I, tomo II, pp. 210-225.

FERNÁNDEZ CONTI, Santiago (2000c). "De príncipe regente a Rey Católico". En José Martínez Millán (dir.), La Corte de Carlos V. Madrid: Sociedad Estatal para la Conmemoración de los Centenarios de Felipe II y Carlos V, vol. I, tomo II, pp. 250-259.

FERNÁNDEZ TEJeRo, Emilia y FERnÁndez MARCos, Natalio (1986). "Biblismo y erasmismo en la España del siglo XVI". En Manuel Revuelta Sañudo y Ciriaco Morón Arroyo (eds.), El erasmismo en España. Santander: Sociedad Menéndez Pelayo, pp. 97-108.

FERNÁNDEZ TERRICABRAS, Ignasi (2018). "De la crisis al viraje. Los inicios de la política confesional de Felipe II". En Michel Boeglin, Ignasi Fernández Terricabras, David Kahn y José Luis Villacañas Berlanga (coords.), Reforma religiosa y disidencia religiosa: la recepción de las doctrinas reformadas en la Península Ibérica en el siglo XVI. Madrid: Casa de Velázquez, pp. 53-73.

FERNÁNDEZ TERRICABRAS, Ignasi (2016). "El fin de las terceras vías: El concilio de Trento y la definición de la frontera confesional". En José Luis Betrán Moya, Bernat Hernández y Doris Moreno (coords.), Identidades y fronteras culturales en el mundo ibérico en la Edad Moderna. Barcelona: Bellaterra, pp. 145-166.

FORELL, George Wolfgang (1994). Martin Luther, theologian of the church, collected essays. St. Paul: Word \& World, Luther Seminary.

García HeRnÁn, Enrique (1999). Francisco de Borja, grande de España. Valencia: Institució Alfons el Magànim.

García Oro, José (2002). Cisneros: el cardenal de España. Barcelona: Ariel.

García Oro, José (1992). El Cardenal Cisneros: vida y empresas. Madrid: Biblioteca de Autores Cristianos, 2 vols.

García VILLOSLADA, Ricardo (1973). Martín Lutero. Madrid: Biblioteca de Autores Cristianos, 2 vols.

GioRDANO, María Laura (2018). "La reforma católica que no pudo ser: los Comentarios al catechismo christiano de Bartolomé de Carranza". En Michel Boeglin, Ignasi Fernández Terricabras, David Kahn y José Luis Villacañas Berlanga (coords.), Reforma religiosa y disidencia religiosa: la recepción de las doctrinas reformadas en la Península Ibérica en el siglo XVI. Madrid: Casa de Velázquez, pp. 127-143.

GÓMEZ-CENTURIÓN JIMÉNEZ, Carlos María (2000). "El felicísimo viaje del príncipe don Felipe, 1548-1551". En Luis Antonio Ribot García (coord.), La monarquia de Felipe II a debate. Madrid: Sociedad Estatal para la Conmemoración de los Centenarios de Felipe II y Carlos V, pp. 19-40.

GonZÁlez Novalín, José Luis (1984). "Reorganización valdesiana de la Inquisición española". En Joaquín Pérez Villanueva y Bartolomé Escandell Bonet (dirs), Historia de la Inquisición en España y América. Madrid: Biblioteca de Autores Cristianos, vol. I, pp. 613-647. 
GonZÁleZ Novalín, José Luis (1979). "La gran batalla de la Inquisición española contra el luteranismo en Castilla". En Ricardo García Villoslada (dir), Historia de la Iglesia en España, III, 2. La España en los siglos XV y XVI. Madrid: Biblioteca de Autores Cristianos, pp. 230-245.

GonzÁlez Novalín, José Luis (1968). El Inquisidor General Fernando de Valdés (1483-1568). Oviedo: Universidad de Oviedo, 2 vols.

GonZÁlez RAmíreZ, David (2016). "Materias deshonestas y de mal ejemplo: programa ideológico y diseño retórico en la narrativa italiana del siglo XVI en España". En Guillermo Carrascón y Chiara Simbolotti (eds.), I novellieri italiani e la loro presenza nella cultura europea: rizomi e palinsesti rinascimentali. Torino: Torino Accademia University Press, pp. 473-490.

GonZALO SÁnCHEZ-MOLERO, José Luis (2014). Felipe II. La educación de un "felicísimo príncipe" (1527-1545). Madrid: Ediciones Polifemo.

GONZALO SÁNCHEZ-MOLERO, José Luis (1998). "La formación de un privado: Ruy Gómez de Silva en la Corte de Castilla (1526-1554)". En José Martínez Millán (dir.), Felipe II (1527-1558): Europa y la Monarquía Católica. Madrid: Parteluz, vol. I, tomo I, pp. 379-400.

Huerga Teruelo, Álvaro (1993). "Fray Luis de Granada, escritor". En Antonio García del Moral y Urbano Alonso del Campo (eds.), Actas del congreso internacional Fray Luis de Granada: su obra y su tiempo. Granada: Universidad de Granada, vol. I, pp. 23-37.

Huerga Teruelo, Álvaro (1988). Historia de los Alumbrados españoles (15701630), IV. Los alumbrados de Sevilla (1605-1630). Madrid: Fundación Universitaria Española.

Huerga Teruelo, Álvaro (1986). "Erasmismo y alumbradismo". En Manuel Revuelta Sañudo y Ciriaco Morón Arroyo (eds.), El erasmismo en España. Santander: Sociedad Menéndez Pelayo, pp. 339-356.

HUIZINGA, Johan (1978). El otoño de la Edad Media. Estudios sobre la forma de la vida y del espíritu durante los siglos XIV y XV en Francia y en los Países Bajos. Trad. J. Gaos. Madrid: Alianza Editorial.

JeDIN, Hubert (1978). Manual de historia de la Iglesia, V. Reforma protestante, reforma católica y contrarreforma. Barcelona: Herder.

JOVER ZAMORA, José María (2001). "Sobre la política exterior de España en tiempo de Carlos V". En Antonio Gallego Morell (coord.), Carlos V (15001558), Granada: Universidad de Granada, pp. 111-208.

Jover ZamORA, José María (1987). Carlos V y los españoles. Madrid: Rialp.

KAMEN, Henry (1999). La Inquisición española: una revisión histórica. Barcelona: Crítica.

Keniston, Hayward (1980). Francisco de los Cobos, secretariode Carlos V. Madrid: Castalia.

LABRADOR ARROYO, Félix (2000a). "Las dimensiones del servicio de la emperatriz Isabel". En José Martínez Millán (dir.), La Corte de Carlos V. Madrid: Sociedad Estatal para la Conmemoración de los Centenarios de Felipe II y Carlos V, vol. I, tomo II, pp. 93-97.

LABRADOR ARROYO, Félix (2000b). "Los servidores de la princesa María Manuela de Portugal". En José Martínez Millán (dir.), La Corte de Carlos V. Madrid: Sociedad Estatal para la Conmemoración de los Centenarios de Felipe II y Carlos V, vol. I, tomo II, pp. 121-125. 
LANGELLA, Simona y RAMIs BARCELÓ, Rafael (coords.) (2021). ¿Qué es la Escuela de Salamanca?. Madrid: Sindéresis.

LAZCANO, Rafael (2017). Lutero. Una vida delante de Dios. Madrid: San Pablo.

LONGHURST, John E. (1958-1963). "Alumbrados, erasmistas y luteranos en el proceso de Juan de Vergara". Cuadernos de historia de Espana (Buenos Aires), (1958), XXVI, pp. 99-163; (1958), XXVII, pp. 102-165; (1959), XXIX-XXX, pp. 266-292; (1960), XXXI-XXXII, pp. 322-356; (1962), XXXVXXXVI, pp. 337-353; (1963), XXXVII-XXXVIII, pp. 356-371.

LucíA MEGíAS, José Manuel (1999). "La Pragmática de 1558 o la importancia del control del Estado en la imprenta española”. Indagación (1999), IV, pp. 195-220.

LUTZ, Heinrich (1992). Reforma y contrarreforma. Trad. Antonio Sáez-Arance. Madrid: Alianza Editorial.

LYNCH, John (1993). Los Austrias (1516-1598). Historia de España, X. Trad. Juan Faci. Barcelona: Crítica.

MALTBY, William S. (1985). El gran duque de Alba. Madrid: Turner.

Mangue, Alberto (2010). El legado de Homero. Trad. C. Criado. Barcelona: Debate.

MÁRQUEZ, Antonio (1980). Literatura e Inquisición en España (1478-1834). Madrid: Taurus.

MÁRQUEZ, Antonio (1972). Los alumbrados: orígenes y filosofía (1525-1559). Madrid: Taurus.

MARTÍNEZ DE BUJANDA, Jesús (2017). "Censura romana y censura española: Principales características de los índices españoles de libros prohibidos". En Javier Vergara Ciordia y Alicia Sala Villaverde (coords.), Censura y libros en la Edad Moderna. Madrid: Dykinson, pp. 19-31.

MARTínEZ DE BUJANDA, Jesús (2000). "Índices de libros prohibidos del siglo XVI". En Joaquín Pérez Villanueva y Bartolomé Escandell Bonet (dirs), Historia de la Inquisición en España y América. Madrid: Biblioteca de Autores Cristianos, vol. III, pp. 773-828.

MARTÍNEZ DE BUJANDA, Jesús (1980). "Literatura e Inquisición en España en el siglo XVI”. En Joaquín Pérez Villanueva (coord.), La Inquisición española. Nueva visión, nuevos horizontes. Madrid: Siglo XXI, pp. 579-592.

MARTíneZ MiLlÁN, José (2013). "Las dos ediciones de Audi Filia y su contexto político religioso". En Juan Aranda Doncel y Antonio Llamas Vela (coords.), San Juan de Ávila, doctor de la Iglesia: actas del congreso internacional. Córdoba: Diputación de Córdoba, pp. 29-48.

MARTínEZ MILLÁN, José (2012). "El nacimiento de la Compañía de Jesús: proyecto religioso y problemas políticos". En José Martínez Millán, Henar Pizarro Llorente y Esther Jiménez Pablo (coords.), Los jesuitas: religión, política y educación (siglos XVI-XVIII). Madrid: Universidad Pontificia de Comillas, vol. I, tomo 1, pp. 21-42.

MARTínEZ MILLÁN, José (2011). Religión, política y tolerancia en la Europa moderna. Madrid: Ediciones Polifemo.

MARTÍNEZ MILLÁN, José (2007). La Inquisición española. Madrid: Alianza Editorial. MARTÍNEZ MILLÁN, José (2003). "Elites de poder en las Cortes de las Monarquías española y portuguesa en el siglo XVI: los servidores de Juana de Austria". Miscelánea Comillas (2003), LXI, pp. 169-202. 
MARTíneZ MiLlÁN, José (2001). "Del humanismo carolino al proceso de confesionalización filipino". En Juan Luis García Hourcade y Juan Manuel Moreno Yuste (coords.), Andrés Laguna: humanismo, ciencia y política en la Europa renacentista. Valladolid: Junta de Castilla y León, pp. 123-159.

MARTÍNEZ MiLLÁN, José (2000a). "La lucha en el contexto de la monarchía universalis: la defensa del catolicismo". En José Martínez Millán (dir.), La Corte de Carlos V. Madrid: Sociedad Estatal para la Conmemoración de los Centenarios de Felipe II y Carlos V, vol. I, tomo II, pp. 171-185.

MARTÍNEZ MILLÁN, José (2000b). "La sucesión en el imperio y el reajuste de los intereses religiosos y dinásticos". En José Martínez Millán (dir.), La Corte de Carlos V. Madrid: Sociedad Estatal para la Conmemoración de los Centenarios de Felipe II y Carlos V, vol. I, tomo II, pp. 267-277.

MARTínEZ MiLláN, José (1994a). "Familia Real y grupos políticos: La princesa Doña Juana de Austria (1535-1573)". En José Martínez Millán (ed.), La corte de Felipe II. Madrid: Alianza Editorial, pp. 73-106.

MARTínEZ MiLLÁN, José (1994b). "En busca de la ortodoxia: el Inquisidor General Diego de Espinosa". En José Martínez Millán (ed.), La corte de Felipe II. Madrid: Alianza Editorial, pp. 189-228.

MARTÍNEZ MILLÁN, José (1992). "Grupos de poder en la corte durante el reinado de Felipe II: la facción ebolista, 1554-1573”. En José Martínez Millán (ed.), Instituciones y elites de poder en la monarquía hispana durante el siglo XVI. Madrid: Universidad Autónoma, pp. 137-197.

MARTÍNEZ MILLÁN, José (1988). "Elites de poder durante el reinado de Carlos V a través de los miembros del Consejo de Inquisición (1516-1558)", Hispania (1988), XLVIII, pp. 103-167.

MARTÍNEZ MILLÁN, José (1980). “Aportaciones a la formación del Estado Moderno y a la política española a través de la censura inquisitorial durante el período 1480-1559". En Joaquín Pérez Villanueva (coord.), La Inquisición española. Nueva visión, nuevos horizontes. Madrid: Siglo XXI, pp.537578.

MARTínEZ MilLÁN, José (1979). "El catálogo de libros prohibidos de 1559". Miscelánea Comillas (1979), XXXVII, pp. 179-217.

Martínez Millán, José y De Carlos Morales, Carlos Javier (1998). Felipe II (1527-1598). La configuración de la monarquía hispana. Salamanca: Junta de Castilla y León.

Morón ARROYo, Ciriaco (1986). "El sistema de Erasmo: origen, originalidad, vigencia”. En Manuel Revuelta Sañudo y Ciriaco Morón Arroyo (eds.), El erasmismo en España. Santander: Sociedad Menéndez Pelayo, pp. 4152.

MuÑOZ SÁNCHEZ, Juan Ramón (2017). “'El mejor de los poetas' para 'el mejor de los príncipes': la «Ulixea de Homero», traducida de griego en lengua castellana por el secretario Gonzalo Pérez, un tratado cortesano de educación principesca", Caliope (2017), XXII, 1, pp. 141-163.

NiETO, José C. (1997). El Renacimiento y la otra España. Gèneve: Librarie Droz.

NiETO, José C. (1979). Juan de Valdés y los orígenes de la Reforma en España e Italia. Trad. Vicente Simón y Ángel Álvarez. México: Fondo de Cultura Económica. 
PARKER, Geoffrey (2010). Felipe II. La biografía definitiva. Trad. de V. E. Gordo, Barcelona: Planeta.

PÉREZ, Joseph (2014), Cisneros, el cardenal de España. Madrid: Taurus.

PÉREZ, Joseph (1978). "Humanismo y escolástica", Cuadernos hispanoamericanos (1978), CCCXXXIV, pp. 28-39.

PINTO CRESPO, Virgilio (1986). "La herejía como problema político. Raíces ideológicas e implicaciones". En Manuel Revuelta Sañudo y Ciriaco Morón Arroyo (eds.), El erasmismo en España. Santander: Sociedad Menéndez Pelayo, pp. 289-304.

Pinto CREsPo, Virgilio (1984). "Control ideológico, censura e «índices de libros prohibidos»". En Joaquín Pérez Villanueva y Bartolomé Escandell Bonet (dirs), Historia de la Inquisición en España y América. Madrid: Biblioteca de Autores Cristianos, vol. I, pp. 648-661.

PINTO CRESPO, Virgilio (1983). Inquisición y control ideológico en la España del siglo XVI. Madrid: Taurus.

PINTO CRESPO, Virgilio (1980). "Institucionalización inquisitorial y censura de libros". En Joaquín Pérez Villanueva (coord.), La Inquisición española. Nueva visión, nuevos horizontes. Madrid: Siglo XXI, pp.513-536.

PizARRo LloRENTE, Henar (2004). Un gran patrón en la corte de Felipe II: don Gaspar de Quiroga. Madrid: Universidad Pontificia de Comillas.

PizARRO LlORENTE, Henar (1994). "El control de la conciencia regia: El confesor real Fray Bernardo de Fresneda". En José Martínez Millán (ed.), La corte de Felipe II. Madrid: Alianza Editorial, pp. 149-188.

Poncela GonzÁlez, Ángel (ed.) (2015). La escuela de Salamanca. Filosofía y Humanismo ante el mundo moderno. Madrid: Verbum.

REDONDO, Augustín (2001). "El doctor Egidio y la predicación evangelista en Sevilla durante los años 1535-1549". En Francisco Sánchez-Montes González y Juan Luis Castellano (coords.), Carlos V. Europeísmo y universalidad. Madrid: Sociedad Estatal para la Conmemoración de los Centenarios de Felipe II y Carlos V, vol. V, pp. 577-598.

REDONDO, Augustín (1965). "Luther et l'Espagne de 1520 à 1536”. Mélanges de la Casa de Velázquez (1965), I, pp. 109-166.

Rıco, Francisco (2011). "Introducción al Lazarillo de Tormes". En Lazarillo de Tormes, ed. F. Rico. Madrid: Real Academia Española, pp. 91-216.

RIVERo RodRíGUEZ, Manuel (2013). "El Mediterráneo occidental como espacio de frontera: el papado, las monarquías ibéricas y el Magreb (1492-1618)". En Maria Antonietta Visceglia (coord.), Papato e politica internazionale nella prima età moderna, Roma: Viella, pp. 323-344.

Rivero Rodríguez, Manuel (2008). La batalla de Lepanto. Cruzada, guerra santa e identidad cristiana. Madrid: Sílex.

Rivero Rodríguez, Manuel (2001). "De la «conservación» a la «razón de Estado»: política exterior de Carlos V y Felipe II". En Dos monarcas y una historia en común: España y Flandes bajo los reinados de Carlos $V$ y Felipe II. Bruselas: Instituto Cervantes.

Rivero Rodríguez, Manuel y MARTínez MilLÁN, José (2000). "Hacia la formación de la monarquía hispana: la hegemonía hispana en Italia (1547-1556)". En José Martínez Millán (dir.), La Corte de Carlos V. Madrid: Sociedad 
Estatal para la Conmemoración de los Centenarios de Felipe II y Carlos V, vol. I, tomo II, pp. 189-208.

RodRíGuez LÓPEZ-ABAdíA, Arturo (2016). "Las dos ediciones del Lazarillo de Amberes de 1553: en 8avo y en 16avo". Etiopicas (2016), XII, pp. 91-103.

RODRíGUEZ LÓPEZ-VÁZQUEZ, Alfredo (2018). "Las dos partes del Lazarillo y su autor. Un estudio de estilometría". Janus (2018), VII, pp. 55-91.

RodRíGuez SALGADO, María José (2000). "Paz ruidosa, guerra sorda: Las relaciones de Felipe II e Inglaterra". En Luis Antonio Ribot García (coord.), La monarquia de Felipe II a debate. Madrid: Sociedad Estatal para la Conmemoración de los Centenarios de Felipe II y Carlos V, pp. 63-120.

RodríGuez Salgado, María José (1996). "Patriotismo y política exterior en la España de Carlos V y Felipe II". En Felipe Ruiz Martín (coord.), La proyección europea de la Monarquía hispánica. Madrid: Universidad Complutense, pp. 49-106.

Rodríguez Salgado, María José (1992). Un Imperio en transición. Carlos V, Felipe II y su mundo. Barcelona: Crítica.

Rodríguez SAN Pedro Bezares, Luis Enrique (2002). "Universidad de la Monarquía Católica, 1555-1700”. En Luis Enrique Rodríguez San Pedro Bezares (coord.), Historia de la Universidad de Salamanca. Salamanca: Universidad de Salamanca, vol. I, pp. 97-146.

SÁNCHEZ MONTES, Juan (1951). Franceses, protestantes, turcos: los españoles ante la política internacional de Carlos V. Madrid: Gómez.

SANZ AYÁN, Carmen (1998). "La regencia de doña Juana de Austria: su dimensión humana, intelectual y política". En La monarquía hispánica Felipe II, un monarca y su época. Madrid: Sociedad Estatal para la Conmemoración de los Centenarios de Felipe II y Carlos V, pp. 137-146.

SELKE DE SÁNCHEZ, Angela (1952). "Algunos datos nuevas sobre los primeros alumbrados. El edicto de 1525 y su relacion con el proceso de Alcaraz". Bulletin hispanique (1952), LIV, pp. 125-152.

SKINNER, Quentin (1993). Los fundamentos del pensamiento político moderno. II. La Reforma. Trad. Juan José Utrilla. Madrid-México: Fondo de Cultura Económica.

Sola CASTAÑo, José Emilio (1988). Un Mediterráneo de piratas: corsarios, renegados y cautivos. Madrid: Tecnos.

TElLECHEA IDígorAS, José Ignacio (2007). El arzobispo Carranza, "tiempos recios". Salamanca: Universidad Pontificia, 4 vols.

TELLECHEA IDÍGORAS, José Ignacio (1984). "La época valdesiana: el proceso del arzobispo Carranza”. En Joaquín Pérez Villanueva y Bartolomé Escandell Bonet (dirs), Historia de la Inquisición en España y América. Madrid: Biblioteca de Autores Cristianos, vol. I, pp. 556-597.

TELLECHEA IDÍGORAS, José Ignacio (1982). "Perfil teológico del protestantismo castellano del siglo XVI”. Diálogo Ecuménico (1982), XVII, pp. 315-373.

TELLECHEA IDÍGORAS, José Ignacio (1965). "Bartolomé Carranza en Flandes. El clima religioso-político en los Países Bajos en 1557-1558". En Hubert Jedin (ed.), Reformata reformanda. Münster: Aschendorff, pp. 317-343.

TELLECHEA IDÍGORAS, José Ignacio (1964). "Bartolomé Carranza y la restauración católica inglesa (1554-1557)”. Anthologica Annua (1964), XII, pp. 159-282. 
TELLECHEA IDÍGORAS, José Ignacio (1963). “Españoles en Lovaina en 1551-1558”. Revista Española de Teología (1963), XXIII, pp. 21-45.

TELLECHEA IDÍGORAS, José Ignacio (1962a). "La censura inquisitorial de Biblias de 1554". Anthologica Annua (1962), X, pp. 89-142.

TELLECHEA IDÍGORAS, José Ignacio (1962b). "Melchor Cano y Bartolomé Carranza. Dos dominicos frente a frente". Hispania Sacra (1962), XV, pp. 5-93.

TELLECHEA IDíGORAS, José Ignacio (1958). "Los prolegómenos jurídicos del proceso de Carranza". Anthologica Annua (1958), VII, pp. 215-336.

THOMAS, Werner (2001). La represión del protestantismo en España, 1515-1648. Leuven: Leuven University Press.

THOMAS, Werner (2000). "La creciente represión del protestantismo en la España carolina”. En José Martínez Millán (coord.), Carlos $V$ y la quiebra del humanismo político en Europa (1530-1558). Madrid: Sociedad Estatal para la Conmemoración de los Centenarios de Felipe II y Carlos V, vol. IV, pp. 281-307.

TORRES COROMINAS, Eduardo (2013). "El Abencerraje: una lección de virtud en los albores del confesionalismo filipino". Revista de Literatura (2013), LXXV, pp. 43-72.

TORRES COROMINAS, Eduardo (2012). "Jorge de Montemayor: un heterodoxo al servicio de la Monarquía hispana”. En José Martínez Millán y Manuel Rivero Rodríguez (coords.), La Corte en Europa. Política y Religión (siglos XVI-XVIII). Madrid: Ediciones Polifemo, vol. II, pp. 1329-1373.

TORRES COROMINAS, Eduardo (2008). "La corte literaria de doña Juana de Austria (1554-1559)". En José Martínez Millán y Ma. Paula Marçal Lourenço (coords.), Las relaciones discretas entre las Monarquías hispana y portuguesa. Las Casas de las reinas. Madrid: Ediciones Polifemo, vol. II, pp. 919-971.

TORRES GARCíA, Arturo (2017). “¿Cuándo, cómo y por qué fue censurado Erasmo?". En Javier Vergara Ciordia y Alicia Sala Villaverde (coords.), Censura y libros en la Edad Moderna. Madrid: Dykinson, pp. 173-232.

VEGA RAmOS, María José (2020). "Buenas y malas biblias: La Censura Generalis (1554) y los inicios de la política expurgatoria de la monarquía hispánica". En Silvia Alexandra Stefan (coord.), Curiosidad y censura en la Edad Moderna. Bucarest: Universidad de Bucarest, pp. 14-43.

VeGa RAmOS, María José (2013). "Notas teológicas y censura de libros en los siglos XVI y XVII". En Cesc Esteve (ed.), Las razones del censor. Control ideológico y censura de libros en la primera Edad Moderna. Barcelona: Universitat Autònoma de Barcelona, pp. 25-53.

Vega Ramos, María José (2012). Disenso y censura en el siglo XVI. Salamanca: Seminario de Estudios Medievales y Renacentistas.

VINCENT, Bernard (2018). "1558 Mostaganem, el desastre del ejército español“. En Xosé M. Núñez Seixas (dir.), Historia mundial de España. Barcelona: Destino, pp. 261-267. 